\title{
Nutritional status and dietary adequacy in rural communities of a protected area in Gabon
}

\author{
S Blaney ${ }^{1,2, *}, M$ Beaudry ${ }^{2}$, Latham $^{3}$ and M Thibault ${ }^{1}$ \\ 'World Wide Fund for Nature, Bayanga, Central African Republic: ${ }^{2}$ Département des Sciences des Aliments et \\ de Nutrition, Université Laval, Québec, Québec, Canada, GIK 7P4: ${ }^{3}$ Division of Nutritional Sciences, \\ Cornell University, Ithaca, NY, USA
}

Submitted 9 July 2007: Accepted 20 February 2009: First published online 30 April 2009

\begin{abstract}
Objective: As part of a larger study designed to understand how to protect the food and nutrition security of individuals living in a protected area of Gabon, we assessed their nutritional status and its relationship to dietary adequacy and health status.

Design: A $7 \mathrm{~d}$ food consumption survey was conducted during each of the two major seasons using a weighing method. Data were also collected on weight, height and health of individuals as well as on sociodemographic characteristics and potential determinants of the nutrition situation.

Setting: Four rural communities were intentionally selected to represent both inland and coastal settings and access to food markets.

Subjects: Approximately 500 individuals representing over $90 \%$ of the population of these communities participated in the survey during each season.

Results: Undernutrition was present in the area, particularly among children $<5$ years of age and the elderly. Health was generally good and under-fives were most frequently ill. Energy, Fe and vitamin A requirements of individuals were generally not satisfied; the opposite was true for protein. The estimated prevalence of inadequate intakes of energy and vitamin A was very high in most age groups. Global nutrient adequacy was associated with nutritional outcome.

Conclusions: Individuals do not eat enough and breast-feeding practices are poor. Many suffer from undernutrition, particularly young children and the elderly. The results confirm the need to investigate the determinants of this poor nutrition situation to ensure that protection of natural resources will not be associated with harm to the well-being of the population.
\end{abstract}

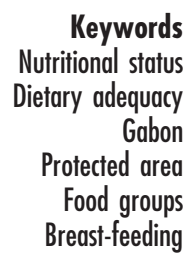

About 300 million persons globally earn part or all of their livelihood from forests, using their resources either directly as food, medicine or fuel, or selling them for income $^{(1)}$. Protected areas designed to preserve biodiversity have been associated with a loss of access to natural resources for people living in and around them ${ }^{(2)}$.

In Gabon, the Gamba Complex of Protected Areas (the Complex) contains some of the most biologically diverse forests on the African continent. In 1993, it was inhabited by approximately 10000 persons spread out in thirtythree villages (2973 inhabitants) and one city (7226 inhabitants) ${ }^{(3)}$. If legislation prohibiting the extraction of natural resources (e.g. wild fruits, bushmeat, fish) ${ }^{(4)}$ were applied consistently, there is serious concern over the possibility of harmonizing the needs of people and the conservation of resources. This is especially the case in rural areas where people rely on natural resources for their livelihood. To design legislation that protects both, it is necessary to understand the relationship between the population and natural resources in the Complex.

In spite of apparent wealth (per capita gross national income \$US 4505), life expectancy in Gabon is 54 years ${ }^{(5)}$. Undernutrition is a concern: national data ${ }^{(6)}$ indicate that $21 \%$ of children $<5$ years of age are stunted and $7 \%$ of women have BMI $<18.5 \mathrm{~kg} / \mathrm{m}^{2}$. At $10878 \mathrm{~kJ}$ (2600 kcal) per capita per d, food availability is estimated at $1088 \mathrm{~kJ}$ $(260 \mathrm{kcal})$ below requirements ${ }^{(7)}$. No data specific to the population of the Complex are available.

Nutritional status is recognized as an indicator of development and well-being ${ }^{(8)}$. For children to grow adequately or for adults to have an adequate nutritional status, several conditions must be met. Their food consumption and their health status - which act in synergy - are the immediate determinants of their nutritional status ${ }^{(9)}$. These, in turn, result from determinants operating at the underlying level of their family and community as well as at the more 
fundamental levels of society. Nutritional status is thus seen as the outcome of processes in society. The present paper describes the nutritional status and dietary adequacy of individuals living in the Complex and examines their relationship as well as that with health status. Future papers will focus on the underlying determinants of the nutrition situation and on their relationship to the use of natural resources.

\section{Methods}

\section{Population and sample}

Over $80 \%$ of the rural population of the Complex lived in twenty-four villages ${ }^{(10-12)}$ : fifteen were inhabited mainly by the Balumbu (799 inhabitants) and nine by the Bapunu (1065). Moreover, two-thirds lived either in the coastal area (656) or on the continent (1091). The former was inhabited mainly by the Balumbu and the latter by the Bapunu. Each village had more or less easy access to a public food market based on distance $(\leq 40 \mathrm{~km}$ or more) or time travelled ( $\leq 20 \mathrm{~min}$ or more).

Sampling intended to represent the two locations, 'coastal' or 'continental', and ease of access to food markets. Villages were non-randomly selected. Each village was assigned to one of four strata as follows: (i) coastal, poor access to food market; (ii) coastal, easy access; (iii) continental, poor access; or (iv) continental, easy access. Within each stratum, the most densely populated village was selected: Sette Cama (first stratum), Ibouka (second), Doussala (third) and Mourindi (fourth stratum; Fig. 1). They represented approximately $30 \%$ of the rural population of the Complex.

The principal investigator (main author) had spent the prior years doing participatory rural appraisals in the Complex which facilitated data collection. During a visit,

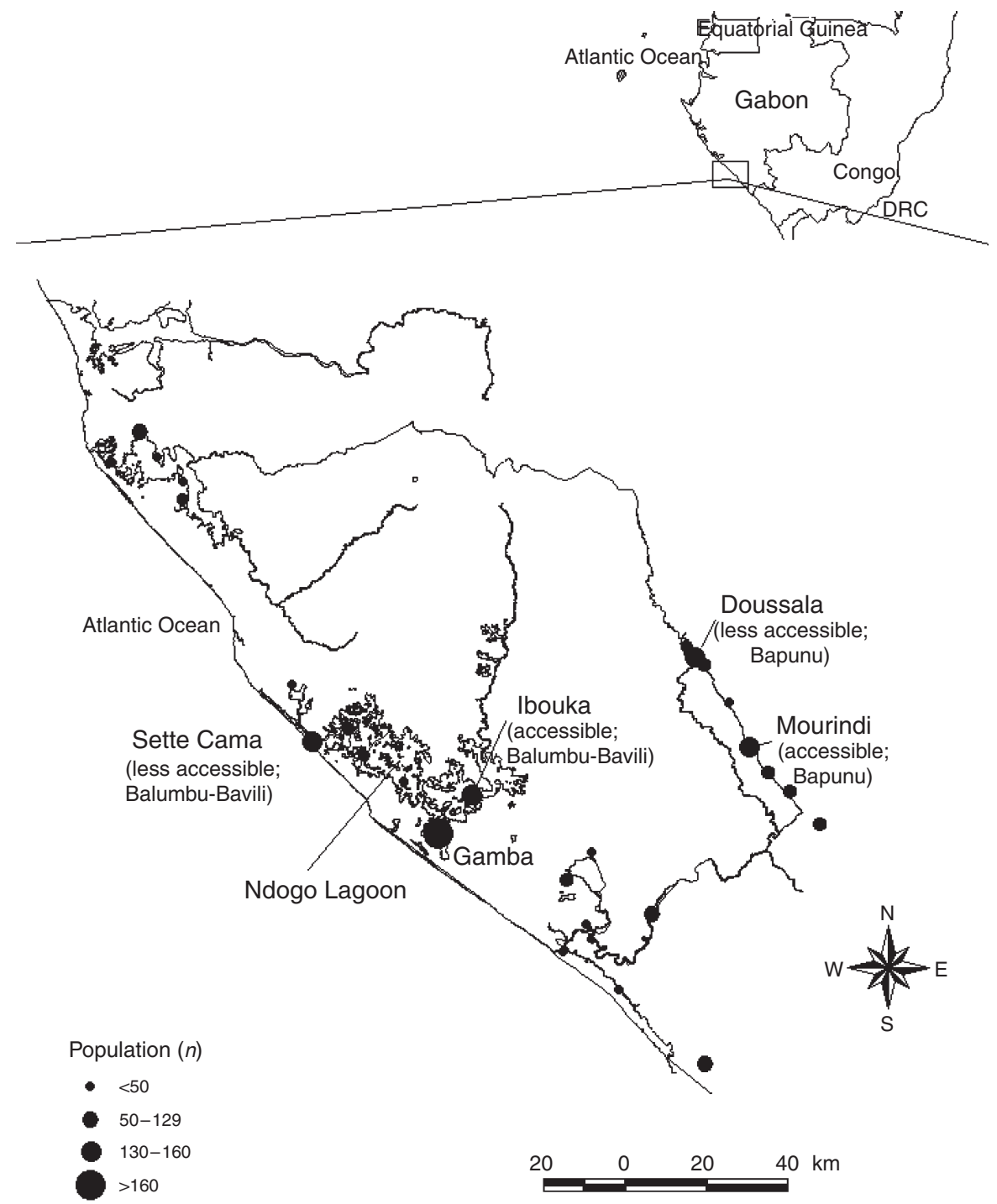

Fig. 1 The Gamba Complex of Protected Areas and location of selected communities 
prior to the actual survey, she informed villagers and local authorities, obtained their verbal approval and invited all households to participate, asking them not to change their pattern of food consumption ${ }^{(13,14)}$. Moreover, during the actual survey in each season, verbal consent was obtained from each household. The present study was also part of a larger project implemented by a conservation organization and for which an agreement had been signed with the government.

\section{Training}

Nine local surveyors and a Peace Corps biologist were trained by the main author on the objectives of the survey, its relevance and standardization of the methods for data collection (e.g. food weighing, observations). All data collection forms were pre-tested, adjusted and finalized during the two-week training. All surveyors were literate, fluent in local languages and motivated to participate. The biologist also functioned as a deputy to the principal investigator.

\section{Data collection}

The survey was carried out during each of the two major rainy and dry seasons (February-April and MaySeptember, 2000). Each village was visited once during each season. Each visit lasted at least $16 \mathrm{~d}$ to encompass two periods of $7 \mathrm{~d}$ so as to cover all households. All surveyors lived in the village during the survey and the same surveyors were involved throughout. The main author reviewed all recorded data daily.

\section{Antbropometric data}

All individuals were weighed with a Uniscale $(150 \mathrm{~kg}$ maximum, $\pm 0 \cdot 1 \mathrm{~kg}$ precision; UNICEF, Copenhagen, Denmark) before breakfast on the first day of the survey in each season. All measures were taken without shoes and with minimum clothing. For persons aged 24 months or older, height was measured vertically with a standardized board $(0-200 \mathrm{~cm}, \pm 0.1 \mathrm{~cm}$ precision; Lindells, Malmo, Sweden). For those younger than 24 months, length was measured horizontally using a locally made board and a fixed non-extensible metric tape $(0-152 \mathrm{~cm}$, $\pm 0 \cdot 1 \mathrm{~cm}$ precision $)^{(15)}$.

\section{Food intake}

Food intake cannot be estimated without error ${ }^{(16)}$. The weighing method provides the most accurate estimate of an individual's food intake ${ }^{(13,14)}$. Moreover, it obviates the population's probable reluctance to disclose information such as that on bushmeat consumption. No validated FFQ exists for the area.

Dietary intake can show important variations from day to day and between seasons ${ }^{(17)}$. A single, daily measurement generally provides a poor estimate of the true nutrient intake of an individual ${ }^{(16,17)}$. The minimum number of days required for a good estimate of the usual intake of energy and macronutrients ranges from 4 to $23 \mathrm{~d}$; for vitamin A, more than $50 \mathrm{~d}$ might be necessary ${ }^{(17-19)}$. We sought an estimate of the usual intake of individuals as opposed to that of a group. The expected variation was unknown. From an examination of studies in similar areas, practical considerations and our knowledge of habits in the area, it was decided to study seven consecutive days of intake. Because of the expected seasonal variation, it was further decided to repeat the study in the two major seasons (total 14d). Among nutrients, energy, protein, Fe and vitamin A were of particular interest. They are often among the most limiting and many wildlife species could be important sources of protein and Fe.

In each season, four teams of two surveyors were each assigned to survey two or three households for one week while the biologist was assigned to one. A $7 \mathrm{~d}$ food consumption survey, as described by Pekkarinen ${ }^{(13)}$, was carried out for each individual in every household. All ingredients included in food preparation as well as cooked individual portions, individual and household leftovers, and snacks or meals taken outside the village were weighed ( $4 \mathrm{~kg}$ maximum, $\pm 0.001 \mathrm{~kg} ;$ Acculab, Newtown, PA, USA). For each breast-fed child, each nursing period taking place between 05.30 and 23.30 hours was recorded. One surveyor was exclusively assigned to follow any individual away from the village for less than $36 \mathrm{~h}$ and to weigh the food that he/she consumed. Unlike in many African settings, the Gabonese eat from individual plates/bowls.

\section{Physical activity}

Each day, the surveyors classified the activities performed by each adult ( $\geq 20$ years) into one of three categories: (i) individual was away from his house to farm/fish/hunt/ gather; (ii) stayed in the village doing activities like cooking, cleaning or fetching water; and (iii) did not perform any of the previous activities (e.g. sick). Each day, the main author visited each household to gather similar information as a reliability check. Physical activity levels were assigned as follows ${ }^{(20)}$;

1. Vigorous: category (i) for $>3 \mathrm{~d} /$ week.

2. Active: category (i) for $\leq 3 \mathrm{~d} /$ week or category (ii) for $>3 \mathrm{~d}$ /week.

3. Light: category (ii) for $\leq 3 \mathrm{~d} /$ week or category (iii) for $>3 \mathrm{~d} /$ week.

\section{Sociodemographics, bealth, food security and care}

Two semi-structured interviews were conducted: (i) with the male head of each household together with his wife and (ii) privately with the latter and any wife and woman caregiver of a child $<5$ years of age in the household. The first interview collected sociodemographic data for each household member (e.g. age, sex, schooling). 
Both interviews collected data on individual health status, care practices, food security and the health environment (e.g. access to safe water and sanitation, housing). Age was confirmed with the identity or the health card. Data were also collected through observation (e.g. health status) and casual probing.

\section{Data analysis}

\section{Nutritional status}

For children $<5$ years of age, height-for-age (stunting), weight-for-height (wasting) and weight-for-age (underweight) indices were derived with the WHO Anthro 2005 software version Beta (2006; WHO, Geneva, Switzerland), which compares measurements with the WHO growth standards ${ }^{(21)}$. Children with indices below -1 sD from the median reference values $(Z$-score $<-1$ ) were considered undernourished, since mild and moderate undernutrition is a contributing cause of deaths in about $50 \%$ of children $<5$ years of age ${ }^{(22,23)}$. In older children and adolescents (5-19 years), BMI-for-age percentile was estimated and compared with the reference values from the Centers for Disease Control and Prevention (CDC) ${ }^{(24)}$ using the Epi Info software version 2002 (CDC, Atlanta, GA, USA). A value below the 5 th percentile indicated thinness ${ }^{(15)}$. In adults, including lactating women, $\mathrm{BMI}<18.5 \mathrm{~kg} / \mathrm{m}^{2}$ indicated underweight $^{(15)}$. Pregnant women ( $n$ 11) were not assessed.

\section{Health status}

Each individual's health status was assessed on the basis of whether or not he/she was ill during the days surveyed in each season and on the nature and duration of each illness. Scores were assigned as follows: (i) $1 \cdot 5=$ individual was not sick; (ii) $1 \cdot 0=$ had a cold, flu, rheumatism or back pain; (iii) $0 \cdot 5=$ had diarrhoea, fever, parasites or toothache; and (iv) $0=$ had an illness from each of categories (ii) and (iii) at the same time (e.g. flu with fever). The score was multiplied by the number of sick days ( 0 to 7 ). The maximum score in each season was $10.5(1.5 \times 7 \mathrm{~d})$, while the minimum was 0 . Using data from both seasons, the mean score was calculated for each individual.

\section{Food and nutrient intake}

Each breast-fed child was classified according to the daily frequency of breast-feeding: (i) 1-3 times; (ii) 4-6 times; or (iii) $\geq 7$ times. His/her daily intake of breast milk was then estimated based on Brown et al.'s classification ${ }^{(25)}$ regarding a low, average and high intake of breast milk. The quantities of food consumed by each individual were entered into the WorldFood Dietary Assessment software version 2.0 (1999; University of California, Berkeley, CA, USA) to calculate the average daily food and nutrient intakes. The nutritive value of foods not originally included was added to the database from information on labels (for eight of 209 foods) or from other sources (sixteen foods) $^{(26-29)}$.
Anthropometric data as well as food and nutrient intakes were transferred to the SPSS statistical software package version 13.0 (2004; SPSS Inc., Chicago, IL, USA) for further analysis. All other data were entered directly into SPSS. Duplicate coding of a random sample of $10 \%$ was carried out and the necessary adjustments made.

\section{Satisfaction of nutrient requirements}

Nutrient requirements were estimated following the WHO/FAO recommendations for energy ${ }^{(20)}$, protein ${ }^{(30)}$, vitamin $\mathrm{A}$ and $\mathrm{Fe}^{(31)}$ for all age groups except for children aged $0-23$ months, where the most recent update was used $^{(32)}$. The degree of satisfaction (\%) of nutrient requirements was calculated by comparing the $7 \mathrm{~d}$ mean daily individual intakes with the estimated individual requirements (recommended dietary allowance for $\mathrm{Fe}$ and protein, recommended safe intake for vitamin A and recommended level of dietary energy intake for energy).

\section{Prevalence of inadequate intakes}

The proportion of the population at risk of inadequacy for protein and vitamin A was estimated by calculating the proportion of individuals below the Estimated Average Requirements (EAR) ${ }^{(30,31,33)}$. The prevalence of inadequate intake of $\mathrm{Fe}$ was assessed using the full probability approach because the distribution of the requirements is asymmetrical $^{(33)}$. No information was available on the range of usual intakes associated with requirement percentiles for a diet with $10 \%$ and $5 \%$ of bioavailable Fe. Therefore, the assessment of the prevalence of inadequate intake of $\mathrm{Fe}$ was based on a diet with $18 \%$, except for children aged $<1$ year, where a diet with $10 \%$ was available ${ }^{(33)}$. It was not assessed for children aged $<6$ months (both seasons, $n 13$ ) nor for pregnant and lactating women ( $n$ 35). The proportion of individuals with energy intakes below $100 \%$ and $75 \%$ of their requirements was simply assessed by comparing individual intakes with the recommended level of daily energy intake ${ }^{(20)}$. Data were adjusted for the day-to-day within-person variation in order to better reflect the inter-person variability of intakes ${ }^{(33)}$.

\section{Nutrient adequacy}

In each season, a global score of nutrient adequacy was calculated for each individual by adding his/her mean degree of satisfaction of requirements for each of the four nutrients and dividing the total by 100 , for a maximum score of 4 . The maximum attributed to each nutrient was $100 \%$ even when the percentage of satisfaction was higher as there is no known advantage to consuming more than required, except perhaps for vitamin A and Fe which can be stored. A global score for both seasons was estimated from the $14 \mathrm{~d}$ mean degree of satisfaction of requirements for the four nutrients. 
Table 1 Sociodemographic characteristics of the population by location and season: non-random sample from the Gamba Complex of Protected Areas, Gabon, 2000

\begin{tabular}{|c|c|c|c|c|c|c|c|c|c|c|c|c|c|c|c|c|c|c|c|c|}
\hline & \multicolumn{8}{|c|}{ Continental villages } & \multicolumn{8}{|c|}{ Coastal villages } & \multicolumn{4}{|c|}{ All villages } \\
\hline & \multicolumn{4}{|c|}{ Rainy } & \multicolumn{4}{|c|}{ Dry } & \multicolumn{4}{|c|}{ Rainy } & \multicolumn{4}{|c|}{ Dry } & \multicolumn{2}{|c|}{ Rainy } & \multicolumn{2}{|c|}{ Dry } \\
\hline & $n$ & $\%$ & Mean & SE & $n$ & $\%$ & Mean & $\mathrm{SE}$ & $n$ & $\%$ & Mean & $\mathrm{SE}$ & $n$ & $\%$ & Mean & $\mathrm{SE}$ & $n$ & $\%$ & $n$ & $\%$ \\
\hline Households & 49 & & & & 49 & & & & 41 & & & & 37 & & & & 90 & & 86 & \\
\hline Individuals & 256 & & & & 289 & & & & 221 & & & & 221 & & & & 477 & & 510 & \\
\hline Male & & 46 & & & & 48 & & & & 45 & & & & 50 & & & & 46 & & 49 \\
\hline Female & & 54 & & & & 52 & & & & 55 & & & & 50 & & & & 54 & & 51 \\
\hline Age & & & $29 \cdot 4$ & 1.5 & & & $26 \cdot 5$ & $1 \cdot 4$ & & & $28 \cdot 5$ & $1 \cdot 7$ & & & $27 \cdot 3$ & $1 \cdot 1$ & & & & \\
\hline 0-23 months & & 5 & & & & 8 & & & & 5 & & & & 6 & & & & 5 & & 7 \\
\hline 24-59 months & & 8 & & & & 9 & & & & 9 & & & & 10 & & & & 9 & & 10 \\
\hline $5-9$ years & & 12 & & & & 12 & & & & 14 & & & & 15 & & & & 13 & & 13 \\
\hline $10-19$ years & & 24 & & & & 26 & & & & 24 & & & & 22 & & & & 24 & & 24 \\
\hline $20-59$ years & & 34 & & & & 32 & & & & 28 & & & & 27 & & & & 31 & & 30 \\
\hline$\geq 60$ years & & 16 & & & & 13 & & & & 20 & & & & 20 & & & & 18 & & 16 \\
\hline Mean household size & & & $5 \cdot 4$ & 0.6 & & & $6 \cdot 0$ & 0.5 & & & $5 \cdot 4$ & 0.4 & & & $5 \cdot 9$ & 0.7 & $5 \cdot 4$ & $0.4+$ & $6 \cdot 0$ & $0.4 \dagger$ \\
\hline Schooling of household head & & & & & & & & & & & & & & & & & & & & \\
\hline None & & 42 & & & & 43 & & & & 34 & & & & 38 & & & & 39 & & 40 \\
\hline $1-3$ years & & 17 & & & & 16 & & & & 22 & & & & 24 & & & & 19 & & 20 \\
\hline $4-6$ years & & 29 & & & & 27 & & & & 29 & & & & 30 & & & & 29 & & 28 \\
\hline$\geq 7$ years & & 12 & & & & 14 & & & & 15 & & & & 8 & & & & 13 & & 12 \\
\hline Activity level ${ }^{*}$ & & & & & & & & & & & & & & & & & & & & \\
\hline Vigorous & & 19 & & & & 14 & & & & 16 & & & & 15 & & & & 18 & & 14 \\
\hline Active & & 79 & & & & 85 & & & & 81 & & & & 81 & & & & 80 & & 84 \\
\hline Light & & 2 & & & & 1 & & & & 3 & & & & 4 & & & & 2 & & 2 \\
\hline
\end{tabular}

${ }^{*}$ For adults $\geq 20$ years.

tSE.

\section{Statistical analysis}

Normality in the distribution pattern was examined by visual inspection of the probability plots and with the KolmogorovSmirnov test. Homogeneity of the variance was assessed with the Levene test. When necessary, logarithmic and square-root transformations were applied to obtain normal distribution patterns and homoscedasticity. For the consumption of major food groups, a value of 0.5 was added before the logarithmic transformation to avoid zero scores.

For continuously distributed variables, a two-factor ANOVA was used to assess differences by season and location and their interaction. Post hoc comparisons used the Least Significant Difference test. The $t$ test was performed to assess differences between two means. For categorical variables, the $\chi^{2}$ test of independence was used to estimate differences in their distribution. Logistic regression was used to estimate the ability of dietary adequacy and health status to predict nutritional status. The goodness-of-fit of the final model was assessed by the Hosmer-Lemeshow test and the power of discrimination was analysed with the area under the receiver-operating characteristic curve. For all analysis, a probability value of 0.05 was accepted as significant.

\section{Results}

\section{Population}

Approximately 500 individuals in some ninety households participated in the survey during each season
(Table 1). On average, $92 \%$ of individuals present in the villages and $95 \%$ of households were involved in both seasons. Others refused to participate mainly because they were unwilling to have their food weighed. Of participant-days surveyed (6909), 6\% were discarded for reasons such as the individual leaving before the end of the survey (160 participant-days), absence for more than $36 \mathrm{~h}$ (128 participant-days) or apparent non-reliability of data* (121 participant-days). The distribution of the population on most sociodemographic characteristics was similar in all villages and generally in accordance with that described in the Demographic and Health Survey ${ }^{(6)}$. About $40 \%$ of household heads had no schooling and over $80 \%$ of adults had an active level of physical activity. Since there was no systematic difference between the more and less accessible villages with regard to nutritional status and the satisfaction of nutrient requirements, data were merged into 'coastal' and 'continental' villages for further analysis.

\section{Nutritional status}

Children $<5$ years old were separated into two groups, 0-23 months and 24-59 months, given their different susceptibility to undernutrition. Overall, undernutrition was observed in all age groups. With the exception of children aged 24-59 months, there was no significant difference in prevalence between seasons, location

\footnotetext{
* For example, meal components such as sauce and meat not weighed
} separately or food weight appeared incorrect. 
Table 2 Prevalence (\%) of undernutrition in each age group by location and season: non-random sample from the Gamba Complex of Protected Areas, Gabon, 2000

\begin{tabular}{|c|c|c|c|c|c|c|c|c|c|c|c|c|}
\hline \multirow[b]{3}{*}{ Age group } & \multicolumn{4}{|c|}{ Continental villages } & \multicolumn{4}{|c|}{ Coastal villages } & \multicolumn{4}{|c|}{ All villages } \\
\hline & \multicolumn{2}{|c|}{ Rainy } & \multicolumn{2}{|c|}{ Dry } & \multicolumn{2}{|c|}{ Rainy } & \multicolumn{2}{|c|}{ Dry } & \multirow{2}{*}{$\frac{\text { Rainy }}{\%}$} & \multirow{2}{*}{$\begin{array}{c}\text { Dry } \\
\%\end{array}$} & \multicolumn{2}{|c|}{ Both* } \\
\hline & $n$ & $\%$ & $n$ & $\%$ & $n$ & $\%$ & $n$ & $\%$ & & & $n$ & $\%$ \\
\hline 0-23 months & 13 & & 21 & & 11 & & 13 & & (n 24) & (n 34) & 41 & \\
\hline $\mathrm{HAZ} \leq-2$ & & (2)‡ & & $19 \cdot 0$ & & (2) & & (2) & $16 \cdot 7$ & $17 \cdot 6$ & & $14 \cdot 6$ \\
\hline$H A Z \leq-1$ & & $38 \cdot 5$ & & $42 \cdot 0$ & & $45 \cdot 5$ & & $23 \cdot 1$ & $41 \cdot 7$ & $35 \cdot 3$ & & $34 \cdot 1$ \\
\hline$W H Z \leq-2$ & & - & & $14 \cdot 3$ & & (1) & & - & (1) & $8 \cdot 8$ & & 4.9 \\
\hline$W H Z \leq-1$ & & $15 \cdot 1$ & & $38 \cdot 1$ & & $27 \cdot 3$ & & $23 \cdot 1$ & $20 \cdot 8$ & $32 \cdot 4$ & & $29 \cdot 3$ \\
\hline$W A Z \leq-2$ & & - & & $19 \cdot 0$ & & (1) & & - & (1) & $11 \cdot 8$ & & $9 \cdot 8$ \\
\hline$W A Z \leq-1$ & & $23 \cdot 1$ & & $38 \cdot 1$ & & $36 \cdot 4$ & & $23 \cdot 1$ & $29 \cdot 2$ & $32 \cdot 4$ & & $26 \cdot 8$ \\
\hline 24-59 months & 21 & & 27 & & 20 & & 23 & & $(n 41)$ & $(n 50)$ & 63 & \\
\hline$H A Z \leq-2$ & & $42 \cdot 9 \S$ & & $11 \cdot 1$ & & $30 \cdot 0$ & & $17 \cdot 4$ & $36 \cdot 6$ & $14 \cdot 0$ & & $20 \cdot 6$ \\
\hline $\mathrm{HAZ} \leq-1$ & & $71 \cdot 4$ & & $55 \cdot 6$ & & $75 \cdot 0$ & & $52 \cdot 2$ & $73 \cdot 2$ & $54 \cdot 0$ & & $60 \cdot 3$ \\
\hline$W H Z \leq-2$ & & - & & $11 \cdot 1$ & & - & & - & - & $6 \cdot 0$ & & $1 \cdot 6$ \\
\hline$W H Z \leq-1$ & & (2) & & $29 \cdot 6$ & & (2) & & (2) & $9 \cdot 8$ & $20 \cdot 0$ & & $17 \cdot 5$ \\
\hline$W A Z \leq-2$ & & (2) & & $11 \cdot 1$ & & $15 \cdot 0$ & & (1) & $12 \cdot 2$ & $8 \cdot 0$ & & $11 \cdot 1$ \\
\hline$W A Z \leq-1$ & & $57 \cdot 1$ & & $48 \cdot 1$ & & $55 \cdot 0$ & & $47 \cdot 8$ & $56 \cdot 1$ & $48 \cdot 0$ & & $49 \cdot 2$ \\
\hline $5-9$ years & 32 & & 35 & & 32 & & 33 & & $(n 64)$ & $(n 68)$ & 82 & \\
\hline BMI-for-age $<5$ th percentile & & $25 \cdot 0$ & & $32 \cdot 4$ & & $9 \cdot 4$ & & $12 \cdot 1$ & $17 \cdot 2$ & 23.5 & & $20 \cdot 7$ \\
\hline $10-19$ yearst & 62 & & 75 & & 51 & & 49 & & (n 114) & (n 124) & 169 & \\
\hline BMI-for-age $<5$ th percentile & & $9 \cdot 8$ & & $13 \cdot 3$ & & $21 \cdot 1$ & & $18 \cdot 4$ & $15 \cdot 0$ & $15 \cdot 3$ & & $14 \cdot 8$ \\
\hline 20-59 yearst & 84 & & 90 & & 59 & & 58 & & (n 149) & (n 152) & 194 & \\
\hline $\mathrm{BMI}<18.5 \mathrm{~kg} / \mathrm{m}^{2}$ & & $12 \cdot 9$ & & $13 \cdot 3$ & & $6 \cdot 9$ & & $12 \cdot 1$ & $10 \cdot 5$ & $12 \cdot 8$ & & $9 \cdot 3$ \\
\hline$\geq 60$ years & 40 & & 38 & & 45 & & 44 & & $(n 85)$ & $(n 82)$ & 101 & \\
\hline $\mathrm{BMl}<18.5 \mathrm{~kg} / \mathrm{m}^{2}$ & & $32 \cdot 5$ & & $26 \cdot 3$ & & $24 \cdot 4$ & & $25 \cdot 0$ & $28 \cdot 2$ & $25 \cdot 6$ & & $25 \cdot 7$ \\
\hline
\end{tabular}

HAZ, height-for-age Z-score; WHZ, weight-for-height Z-score; WAZ, weight-for-age Z-score.

${ }^{*}$ For each individual present in both seasons, mean nutritional status was calculated; some were present only in one season (e.g. newborns). tNutritional status of pregnant women was not assessed ( $n 1,10-19$ years; $n 10,20-59$ years).

$\ddagger$ When the number of individuals in a category was $\leq 2$, the percentage was not calculated.

$\S$ Difference in distribution between seasons in continental villages $(P=0.014)$.

(Table 2) or gender (results not shown). As compared with the dry season, more children aged 24-59 months were stunted in the rainy season. Their mean height-for-age $Z$-score was also lower (rainy $-1 \cdot 4(\operatorname{se~} 0 \cdot 1) v$. dry $-1 \cdot 0$ (SE $0 \cdot 1), P=0 \cdot 017$; results not shown). Children $<5$ years old showed the highest rates of undernutrition, followed by the elderly, children aged 5-9 years, adolescents and adults. The mean BMI was $22 \cdot 1(\operatorname{SE} 0 \cdot 2) \mathrm{kg} / \mathrm{m}^{2}$ in adults and $20 \cdot 8(\mathrm{se} 0 \cdot 3) \mathrm{kg} / \mathrm{m}^{2}$ for the elderly. In children $<5$ years old, mean height-for-age $Z$-score was $-0 \cdot 9$ ( $\operatorname{se~} 0 \cdot 1$ ), mean weight-for-height $Z$-score was $-0 \cdot 3$ (SE $0 \cdot 1$ ) and mean weight-for-age $Z$-score $-0 \cdot 8$ ( $\operatorname{se~} 0 \cdot 1$ ). About $9 \%$ of adults aged 20-59 years and $26 \%$ of the elderly were undernourished. No clinical signs of severe undernutrition were apparent.

Overall, $14.9 \%$ and $11.9 \%$ of adults and the elderly showed $\mathrm{BMI} \geq 25 \cdot 0 \mathrm{~kg} / \mathrm{m}^{2}$, while one child aged $5-9$ years and two adolescents were at risk of overweight (BMI-for-age $>85$ th percentile) $^{(15)}$. There were no children $<5$ years old with a mean weight-for-height $Z$-score above +2 (results not shown).

\section{Health status}

No illness was reported during the days surveyed for about half of the children aged $<5$ years or for most individuals in other groups, nor were they obviously ill (Table 3). No difference was observed between age groups in the mean score of health status among sick individuals. Individuals were therefore eventually classified as either sick or not sick.

\section{Food intake}

Tables 4 and 5 show the arithmetic means of the quantity of each food group consumed daily per capita; analyses were however done on transformed data. Tubers/cereals/breads was by far the main food group consumed, followed by alcoholic beverages (Table 4). Most of the fish/shellfish was consumed in coastal villages, while more of the meat/ chicken/eggs was eaten in continental villages. The intake of fruits and vegetables was far below the $400 \mathrm{~g} / \mathrm{d}$ recommended $^{(34)}$. Fortified foods were almost non-existent. The use of nutrient supplements was absent.

Overall, tubers, cereals and breads provided most of the energy (Table 5). They also contributed approximately half of the Fe and an important proportion of protein and pro-vitamin A. Vegetables contributed approximately 50\% of the vitamin A in each season (between $97 \cdot 0$ (SE 8.8) and $314 \cdot 7$ (sE $15 \cdot 7)$ retinol equivalents (RE)/4184 kJ (1000 kcal)) and somewhat more in continental (between 215.0 (SE 11.2) and $314 \cdot 7$ (SE 15.7) RE/4184kJ) as compared with coastal settings (between 97.0 (SE 8.8) and 160.0 (SE 11.1) $\mathrm{RE} / 4184 \mathrm{~kJ}$; results not shown). Together, fish/shellfish and meat/chicken/eggs provided about $10 \%$ of vitamin A 
Table 3 Nutrient adequacy and health status* for each age group by location and season: non-random sample from the Gamba Complex of Protected Areas, Gabon, 2000

\begin{tabular}{|c|c|c|c|c|c|c|c|c|c|c|c|c|c|c|c|c|c|c|c|c|c|}
\hline \multirow[b]{3}{*}{ Age group } & \multicolumn{6}{|c|}{ Continental villages } & \multicolumn{6}{|c|}{ Coastal villages } & \multicolumn{9}{|c|}{ All villages } \\
\hline & \multicolumn{3}{|c|}{ Rainy } & \multicolumn{3}{|c|}{ Dry } & \multicolumn{3}{|c|}{ Rainy } & \multicolumn{3}{|c|}{ Dry } & \multicolumn{3}{|c|}{ Rainy } & \multicolumn{3}{|c|}{ Dry } & \multicolumn{3}{|c|}{ Botht } \\
\hline & $n$ & Mean & $\mathrm{SE}$ & $n$ & Mean & $\mathrm{SE}$ & $n$ & Mean & SE & $n$ & Mean & SE & $n$ & Mean & SE & $n$ & Mean & SE & $n$ & Mean & SE \\
\hline \multicolumn{22}{|l|}{ 0-23 months } \\
\hline $\begin{array}{l}\text { Nutrient adequacy } \\
\text { Health status }\end{array}$ & 13 & $3 \cdot 2$ & 0.2 & 21 & $3 \cdot 3$ & $0 \cdot 1$ & 11 & $2 \cdot 9$ & $0 \cdot 1$ & 13 & $3 \cdot 2$ & $0 \cdot 1$ & 24 & $3 \cdot 0$ & $0 \cdot 1$ & 34 & $3 \cdot 3$ & $0 \cdot 1$ & 41 & $3 \cdot 2 \ddagger$ & $0 \cdot 1$ \\
\hline Not sick & 9 & & & 9 & & & 3 & & & 4 & & & 12 & & & 13 & & & 17 & & \\
\hline $\begin{array}{c}\text { Sick } \\
\text { 24-59 months }\end{array}$ & 4 & $8 \cdot 3$ & 0.9 & 12 & $6 \cdot 0$ & 0.8 & 8 & $7 \cdot 3$ & $1 \cdot 1$ & 9 & $6 \cdot 5$ & 0.9 & 12 & $7 \cdot 6$ & 0.8 & 21 & $6 \cdot 3$ & 0.6 & 24 & $7 \cdot 5$ & $0 \cdot 3$ \\
\hline $\begin{array}{l}\text { Nutrient adequacy } \\
\text { Health status }\end{array}$ & 21 & $2 \cdot 9$ & $0 \cdot 1$ & 27 & $2 \cdot 7$ & $0 \cdot 1$ & 20 & $2 \cdot 9$ & $0 \cdot 1$ & 23 & $3 \cdot 1$ & $0 \cdot 1$ & 41 & $2 \cdot 9$ & $0 \cdot 1$ & 50 & $2 \cdot 9$ & $0 \cdot 1$ & 63 & $2 \cdot 9$ & $0 \cdot 1$ \\
\hline Not sick & 11 & & & 8 & & & 17 & & & 17 & & & 28 & & & 25 & & & 33 & & \\
\hline $\begin{array}{c}\text { Sick } \\
5-9 \text { years }\end{array}$ & 10 & $6 \cdot 8$ & 0.7 & 19 & $6 \cdot 7$ & 0.6 & 3 & $7 \cdot 3$ & $1 \cdot 0$ & 6 & $7 \cdot 9$ & 0.6 & 13 & 6.9 & 0.6 & 25 & $7 \cdot 0$ & 0.5 & 30 & $7 \cdot 5$ & $0 \cdot 4$ \\
\hline $\begin{array}{l}\text { Nutrient adequacy } \\
\text { Health status }\end{array}$ & 32 & $2 \cdot 9$ & $0 \cdot 1$ & 35 & $2 \cdot 9$ & $0 \cdot 1$ & 32 & $2 \cdot 9$ & $0 \cdot 1$ & 33 & $3 \cdot 2$ & $0 \cdot 1$ & 64 & $2 \cdot 9$ & $0 \cdot 1$ & 68 & $3 \cdot 0$ & $0 \cdot 1$ & 82 & $3 \cdot 0$ & $0 \cdot 1$ \\
\hline Not sick & 30 & & & 29 & & & 29 & & & 30 & & & 59 & & & 59 & & & 69 & & \\
\hline Sick & 2 & $8 \cdot 8$ & $1 \cdot 3$ & 6 & $7 \cdot 2$ & 0.8 & 3 & $8 \cdot 2$ & $0 \cdot 3$ & 3 & $7 \cdot 7$ & 0.7 & 5 & $8 \cdot 4$ & 0.5 & 9 & $7 \cdot 3$ & 0.5 & 13 & $8 \cdot 2$ & $0 \cdot 5$ \\
\hline $10-19$ years & & & & & & & & & & & & & & & & & & & & & \\
\hline $\begin{array}{l}\text { Nutrient adequacy } \\
\text { Health status }\end{array}$ & 62 & $2 \cdot 7$ & $0 \cdot 1$ & 75 & $2 \cdot 6$ & $0 \cdot 1$ & 52 & $2 \cdot 6$ & $0 \cdot 1$ & 49 & $2 \cdot 9$ & $0 \cdot 1$ & 114 & $2 \cdot 7$ & $0 \cdot 1$ & 124 & $2 \cdot 7$ & $0 \cdot 1$ & 169 & $2 \cdot 7$ & $0 \cdot 1$ \\
\hline Not sick & 61 & & & 72 & & & 45 & & & 47 & & & 106 & & & 119 & & & 156 & & \\
\hline Sick & 1 & $8 \cdot 5$ & & 3 & $6 \cdot 8$ & $1 \cdot 7$ & 7 & $7 \cdot 1$ & $1 \cdot 0$ & 2 & $7 \cdot 5$ & 0.5 & 8 & $7 \cdot 3$ & 0.9 & 5 & $7 \cdot 1$ & 0.9 & 13 & $8 \cdot 4$ & $0 \cdot 3$ \\
\hline $20-59$ years & & & & & & & & & & & & & & & & & & & & & \\
\hline $\begin{array}{l}\text { Nutrient adequacy } \\
\text { Health status }\end{array}$ & 88 & $3 \cdot 1$ & $0 \cdot 1$ & 93 & $3 \cdot 1$ & $0 \cdot 1$ & 61 & $3 \cdot 0$ & $0 \cdot 1$ & 59 & $3 \cdot 0$ & $0 \cdot 1$ & 149 & $3 \cdot 1$ & $0 \cdot 1$ & 152 & $3 \cdot 1$ & $0 \cdot 1$ & 194 & $3 \cdot 1$ & $0 \cdot 1$ \\
\hline Not sick & 73 & & & 81 & & & 49 & & & 45 & & & 122 & & & 125 & & & 144 & & \\
\hline $\begin{array}{c}\text { Sick } \\
\geq 60 \text { years }\end{array}$ & 15 & $8 \cdot 1$ & 0.2 & 12 & $7 \cdot 1$ & 0.8 & 12 & $6 \cdot 7$ & $0 \cdot 6$ & 14 & $6 \cdot 5$ & 0.6 & 27 & $7 \cdot 5$ & 0.3 & 27 & $6 \cdot 8$ & 0.5 & 50 & $8 \cdot 3$ & $0 \cdot 2$ \\
\hline $\begin{array}{l}\text { Nutrient adequacy } \\
\text { Health status }\end{array}$ & 40 & $3 \cdot 2$ & 0.1 & 38 & $3 \cdot 3$ & $0 \cdot 1$ & 45 & $3 \cdot 0$ & $0 \cdot 1$ & 44 & $3 \cdot 4$ & $0 \cdot 1$ & 85 & $3 \cdot 1$ & $0 \cdot 1$ & 82 & $3 \cdot 3$ & $0 \cdot 1$ & 101 & $3 \cdot 3$ & $0 \cdot 1$ \\
\hline Not sick & 32 & & & 30 & & & 37 & & & 28 & & & 69 & & & 58 & & & 68 & & \\
\hline Sick & 8 & $6 \cdot 8$ & 0.6 & 8 & $6 \cdot 9$ & 0.6 & 8 & $6 \cdot 3$ & $0 \cdot 6$ & 16 & $6 \cdot 7$ & 0.4 & 16 & $6 \cdot 6$ & 0.4 & 24 & $6 \cdot 8$ & 0.3 & 33 & $7 \cdot 9$ & $0 \cdot 4$ \\
\hline
\end{tabular}

*Mean score of health status was calculated only for sick individuals.

tRefers to the mean of each individual's score for each week of the survey. ‡Difference between age groups $(P<0.05)$.

(between 17.8 (sE 1.4) and 24.6 (se 1.7) RE/4184kJ), 58\% of protein and $26 \%$ of Fe.

All children aged $<6$ months were breast-fed ( $n$ 13), although only two exclusively; breast milk probably contributed approximately 90 (SE 3) \% of their energy intake. About $50 \%$ of children aged $6-23$ months ( $n$ 41) were breast-fed. Breast milk was estimated to provide 48 (SE 8) \% of energy in children aged 6-11 months and 10 (SE 5) \% in children aged 12-23 months.

\section{Nutrient intakes and satisfaction of requirements}

Overall, protein provided 14 (SE $0 \cdot 1$ ) \% of energy, fat 21 (SE $0 \cdot 2$ ) \% and carbohydrates 65 (SE 0.5) \%. Populations living in coastal villages had better energy intakes (Table 6) and generally better satisfied their requirements (Table 7), particularly in the dry season. Nevertheless, energy requirements were generally far from satisfied in all groups.

Protein and Fe intakes per $4184 \mathrm{~kJ}$ (1000 kcal) did not vary with season. However, in each season, protein intake was higher in coastal villages (Table 6). Although generally fulfilled, protein requirements were better satisfied in coastal villages as well as in the dry season (Table 7). Vitamin A intake (Table 6) and the satisfaction of requirements (Table 7) were generally low, although higher in continental villages and in the rainy season. Fe intake was highest in continental villages (Table 6) although Fe requirements were far from satisfied, particularly among children and adolescents (Table 7). In both seasons, Fe requirements of males aged 10-19 years and 20-59 years were better satisfied (between 60 (sE 3) \% and 101 (SE 4) \%) than those of females (between 32 (SE 3) \% and 57 (SE 3) \%, $P<0 \cdot 001$; results not shown).

\section{Prevalence of inadequate intakes}

Between $37 \%$ and $100 \%$ of individuals did not satisfy their energy requirements, whereas between $9 \%$ and $92 \%$ did not attain $75 \%$ (Figs 2 and 3 ). The prevalence of inadequate intake of protein was much lower than that of energy but still a problem, especially among adolescents in continental villages (Figs 2 and 3). With the exception of continental villages during the rainy season, at least $60 \%$ of individuals had intakes of vitamin A below the EAR. The prevalence of inadequate intake of Fe appeared lower than that for energy or vitamin A, although still of concern; it was generally highest among children aged $<5$ years. 
Table 4 Daily per capita intake $(\mathrm{g})$ of each food group by location and season: non-random sample from the Gamba Complex of Protected Areas, Gabon, 2000

\begin{tabular}{|c|c|c|c|c|c|c|c|c|c|c|c|c|}
\hline \multirow[b]{3}{*}{ Food group } & \multicolumn{4}{|c|}{ Continental villages } & \multicolumn{4}{|c|}{ Coastal villages } & \multicolumn{4}{|c|}{ All villages } \\
\hline & \multicolumn{2}{|c|}{ Rainy (n 256) } & \multicolumn{2}{|c|}{ Dry (n 289) } & \multicolumn{2}{|c|}{ Rainy (n 221) } & \multicolumn{2}{|c|}{ Dry (n 221) } & \multicolumn{2}{|c|}{ Rainy (n 477) } & \multicolumn{2}{|c|}{ Dry $(n 510)$} \\
\hline & Mean & SE & Mean & SE & Mean & SE & Mean & SE & Mean & SE & Mean & SE \\
\hline Tubers/cereals/breads & $648 \cdot 2$ & $24 \cdot 0$ & $570 \cdot 2$ & $33 \cdot 3$ & $480 \cdot 7 \S$ & $24 \cdot 2$ & $645 \cdot 9$ & $61 \cdot 0$ & 571.9 & $19 \cdot 2$ & $602 \cdot 8$ & $32 \cdot 4$ \\
\hline Meat/chicken/eggs & $61 \cdot 0 \ddagger$ & $7 \cdot 6$ & $44 \cdot 2 \ddagger$ & $7 \cdot 3$ & $23 \cdot 0^{\circ}$ & $4 \cdot 4$ & $16 \cdot 5$ & $4 \cdot 8$ & $43 \cdot 6 \|$ & $5 \cdot 0$ & $32 \cdot 3$ & 4.9 \\
\hline Fish/shellfish & $39 \cdot 8 \ddagger$ & $6 \cdot 4$ & $38 \cdot 3 \ddagger$ & $4 \cdot 6$ & $188 \cdot 2$ & $14 \cdot 3$ & $211 \cdot 4$ & $28 \cdot 5$ & $107 \cdot 4$ & $10 \cdot 8$ & $112 \cdot 8$ & $15 \cdot 5$ \\
\hline Vegetables & $92 \cdot 8 \ddagger, \S$ & $7 \cdot 8$ & $46 \cdot 5$ & $6 \cdot 0$ & $34 \cdot 5$ & $5 \cdot 6$ & $50 \cdot 2$ & $12 \cdot 2$ & $66 \cdot 2$ & $5 \cdot 8$ & $48 \cdot 1$ & $6 \cdot 3$ \\
\hline Fruits & $47 \cdot 7$ & $12 \cdot 4$ & $41 \cdot 9$ & $9 \cdot 8$ & $10 \cdot 3$ & $2 \cdot 2$ & $36 \cdot 4$ & $16 \cdot 0$ & $30 \cdot 6$ & $7 \cdot 1$ & $39 \cdot 6$ & $8 \cdot 8$ \\
\hline Nuts/beans & $15 \cdot 7$ & $2 \cdot 5$ & $10 \cdot 0$ & $2 \cdot 1$ & $3 \cdot 7$ & $0 \cdot 9$ & $3 \cdot 7$ & $1 \cdot 5$ & $10 \cdot 2$ & $1 \cdot 6$ & $7 \cdot 3$ & $1 \cdot 4$ \\
\hline Milk/cheese* & $2 \cdot 4$ & 0.9 & $1 \cdot 2$ & 0.5 & $3 \cdot 8$ & $2 \cdot 1$ & $3 \cdot 5$ & 0.8 & $3 \cdot 0$ & $1 \cdot 1$ & $2 \cdot 2$ & 0.5 \\
\hline Sugars/sweets & $14 \cdot 0 \ddagger$ & $1 \cdot 8$ & $21 \cdot 6 \ddagger$ & $3 \cdot 6$ & $17 \cdot 0$ & $2 \cdot 9$ & $61 \cdot 3$ & $14 \cdot 5$ & $15 \cdot 4 \S$ & $1 \cdot 7$ & $38 \cdot 7$ & $6 \cdot 9$ \\
\hline Fats/oils & $1 \cdot 1$ & $0 \cdot 3$ & $4 \cdot 0$ & $1 \cdot 4$ & $1 \cdot 3$ & $0 \cdot 4$ & $2 \cdot 5$ & 1.9 & $1 \cdot 2$ & 0.2 & $3 \cdot 4$ & $1 \cdot 1$ \\
\hline Non-alcoholic beverages & $13 \cdot 6$ & $3 \cdot 4$ & $5 \cdot 6$ & $1 \cdot 4$ & $39 \cdot 7$ & $5 \cdot 5$ & $65 \cdot 6$ & $7 \cdot 0$ & $25 \cdot 5$ & $3 \cdot 4$ & $31 \cdot 4$ & $4 \cdot 5$ \\
\hline Mixtures (sauces) & $5 \cdot 3 \ddagger$ & $1 \cdot 6$ & $1 \cdot 4 \ddagger$ & 0.6 & $21 \cdot 3$ & $7 \cdot 2$ & $3 \cdot 8$ & $1 \cdot 3$ & $12 \cdot 6 \S$ & $3 \cdot 5$ & $2 \cdot 4$ & 0.2 \\
\hline Infant foods & $0 \cdot 3$ & $0 \cdot 2$ & - & - & $0 \cdot 3$ & $0 \cdot 2$ & $1 \cdot 4$ & 0.8 & 0.3 & $0 \cdot 1$ & 0.6 & 0.4 \\
\hline Alcoholic beveragest & $175 \cdot 6 \ddagger$ & $37 \cdot 3$ & $166 \cdot 6 \ddagger$ & $29 \cdot 7$ & $245 \cdot 2$ & $37 \cdot 8$ & 319.5 & $51 \cdot 3$ & $207 \cdot 7$ & $27 \cdot 0$ & $233 \cdot 2$ & 28.9 \\
\hline
\end{tabular}

*Includes breast milk.

tMeans calculated for adults $\geq 20$ years.

‡Difference between locations $(P<0 \cdot 01)$

§Difference between seasons $(P<0.01)$

IIDifference between seasons $(P<0.05)$.

\section{Nutrient adequacy}

Children aged 0-23 months and the elderly had the best scores of global nutrient adequacy, while adolescents had the lowest (Table 3). Adult (mean score 3·3 (sE 0·1), $n$ 90) and adolescent males $(2 \cdot 9$ (SE $0 \cdot 1), n 85)$ had better scores than their female counterparts $(2.9$ (SE 0.1) and 2.5 (SE 0·1), $n 104$ and $n$ 84, $P=0 \cdot 000$; results not shown).

\section{Association between nutritional status, nutrient adequacy and bealth status}

In logistic regression analyses, both the global score on nutrient adequacy (continuous) and health status (not sick) predicted nutritional outcome (Table 8 , model 1). When age group was added (model 2), health status was no longer significant and the odds for nutrient adequacy increased $(\mathrm{OR}=1 \cdot 64,95 \% \mathrm{CI} 1 \cdot 13,2 \cdot 39)$. Being a child aged $0-9$ years or elderly appeared to be associated with a greater risk of undernutrition. Introducing gender and location (or ethnic group) did not change the results (not shown). The discriminative power of the final equation was acceptable at $0 \cdot 72$ (well-nourished $v$. undernourished) ${ }^{(35)}$. Similar results were obtained when weight-for-age was substituted as an indicator of undernutrition for children aged $<5$ years (results not shown).

\section{Discussion}

Undernutrition is important in the Complex, especially among the young, as opposed to overweight which affects only adults and the elderly. Using the criterion of $Z$-score $\leq-1$ (mild undernutrition), $50 \%$ of children $<5$ years of age were stunted, $22 \%$ were wasted and $40 \%$ were underweight. In a normal population, only $2 \cdot 3 \%$ of children would be expected to have $Z$-score $\leq-2$ (moderate and severe undernutrition ${ }^{(15)}$ ). However, in the present study, this was the case for $18 \%$ of the underfives for stunting and $11 \%$ for underweight, a serious concern given their link to child mortality ${ }^{(22,23)}$. Before 24 months, $15 \%$ were stunted, a particularly concerning situation given that it is nearly irreversible after the age of 2-3 years.

As suggested by the logistic regression results, nutrient adequacy was a more important predictor of nutritional status than health status after controlling for age. However, the majority of individuals were not ill during the survey; in addition, our measure of health was highly summarized and did not capture past illnesses. Yet, undernutrition did not always parallel results on the prevalence of inadequate intakes of energy or on global nutrient adequacy. Overall, adults (20-59 years) had the lowest rate of undernutrition but a very high prevalence of inadequate intake of energy, whereas the elderly had a high prevalence of undernutrition with the best score on nutrient adequacy.

It is unlikely that the dietary intake of adults was underestimated as households were under continuous surveillance. Given our prior knowledge of this population and our relationship with them, it is also unlikely that they changed their diet because of our presence. Moreover, we did investigate their diet for $7 \mathrm{~d}$ in each season, making it difficult for them to restrict their intakes for more than a day or two as they had to maintain their regular activities. Their energy requirements could have been overestimated either through an error in measuring height or physical activity, or by basing estimates on desirable weight instead of actual weight. It is unlikely that height was inaccurate since we obtained a correlation 
Table 5 Contribution (\%) of each food group to nutrient intake by location and season: non-random sample from the Gamba Complex of Protected Areas, Gabon, 2000

\begin{tabular}{|c|c|c|c|c|c|c|c|c|c|c|c|c|c|c|c|c|}
\hline \multirow[b]{4}{*}{ Food group } & \multicolumn{16}{|c|}{ Continental villages } \\
\hline & \multicolumn{4}{|c|}{ Energy } & \multicolumn{4}{|c|}{ Protein } & \multicolumn{4}{|c|}{ Vitamin A/pro-vitamin A } & \multicolumn{4}{|c|}{$\mathrm{Fe}$} \\
\hline & \multicolumn{2}{|c|}{ Rainy (n 256) } & \multicolumn{2}{|c|}{ Dry $(n 289)$} & \multicolumn{2}{|c|}{ Rainy (n 256) } & \multicolumn{2}{|c|}{ Dry $(n 289)$} & \multicolumn{2}{|c|}{ Rainy ( $n$ 256) } & \multicolumn{2}{|c|}{ Dry (n 289) } & \multicolumn{2}{|c|}{ Rainy (n 256) } & \multicolumn{2}{|c|}{ Dry $(n 289)$} \\
\hline & Mean & SE & Mean & SE & Mean & SE & Mean & SE & Mean & SE & Mean & SE & Mean & SE & Mean & SE \\
\hline Tubers/cereals/breads & $65 \cdot 1$ & $1 \cdot 0$ & $68 \cdot 6 \neq$ & $1 \cdot 0$ & $30 \cdot 1 \S$ & 0.9 & $32 \cdot 3 \S$ & 0.9 & $25 \cdot 3$ & 1.5 & $26 \cdot 3 \S$ & 1.5 & $47 \cdot 2 \dagger$ & $1 \cdot 0$ & $56 \cdot 9+$ & 0.9 \\
\hline Meat/chicken/eggs & $7 \cdot 1 \dagger$ & 0.6 & $6 \cdot 4 t$ & 0.4 & $34 \cdot 4 t$ & $1 \cdot 6$ & $31 \cdot 5 t$ & $1 \cdot 4$ & $1 \cdot 3+$ & 0.3 & $1 \cdot 8 t$ & 0.4 & $21 \cdot 7 \dagger$ & $1 \cdot 2$ & $22 \cdot 6+$ & $1 \cdot 1$ \\
\hline Fish/shellfish & $3 \cdot 4+$ & 0.3 & $3 \cdot 9+$ & $0 \cdot 2$ & $8 \cdot 8+, \S$ & $1 \cdot 1$ & $25 \cdot 7 \dagger$ & $1 \cdot 0$ & $3 \cdot 3+$ & 0.4 & $2 \cdot 2+$ & 0.3 & $6 \cdot 0+$ & $0 \cdot 4$ & $6 \cdot 1+$ & $0 \cdot 3$ \\
\hline Vegetables & $8 \cdot 8+$ & 0.4 & $5 \cdot 3+$ & 0.3 & $4 \cdot 4 t$ & $0 \cdot 3$ & $0 \cdot 9+$ & $0 \cdot 1$ & $60 \cdot 4 t$ & $1 \cdot 9$ & $55 \cdot 5 t$ & 1.9 & $10 \cdot 1 \dagger$ & $0 \cdot 6$ & $3 \cdot 9$ & $0 \cdot 2$ \\
\hline Fruits & $1 \cdot 2 t$ & $0 \cdot 2$ & $2 \cdot 3+$ & $0 \cdot 2$ & $1 \cdot 1+$ & $0 \cdot 1$ & $1 \cdot 3+$ & $0 \cdot 1$ & 0.8 & 0.2 & $1 \cdot 2+$ & $0 \cdot 2$ & $2 \cdot 7 t$ & 0.4 & $2 \cdot 6+$ & 0.2 \\
\hline Nuts/beans & $3 \cdot 2+$ & $0 \cdot 3$ & $2 \cdot 5+$ & $0 \cdot 2$ & $5 \cdot 5+$ & 0.5 & $2 \cdot 5+$ & 0.3 & $0 \cdot 3$ & $0 \cdot 1$ & $2 \cdot 4+$ & 0.6 & $6 \cdot 4$ & 0.5 & $2 \cdot 7$ & 0.3 \\
\hline Milk/cheese* & $2 \cdot 9$ & 0.9 & $4 \cdot 6 \ddagger$ & $1 \cdot 1$ & $2 \cdot 9$ & 0.9 & $4 \cdot 5 \ddagger$ & $1 \cdot 1$ & $3 \cdot 4$ & $1 \cdot 1$ & 4.9 & $1 \cdot 2$ & $1 \cdot 5$ & $0 \cdot 7$ & $2 \cdot 5 \ddagger$ & $0 \cdot 7$ \\
\hline Sugars/sweets & $2 \cdot 6 \ddagger$ & 0.2 & $2 \cdot 5 \ddagger$ & $0 \cdot 2$ & - & - & - & - & - & - & - & - & - & - & - & - \\
\hline Fats/oils & $1 \cdot 0$ & 0.4 & $1 \cdot 0 t$ & $0 \cdot 1$ & - & - & - & - & $0 \cdot 2$ & $0 \cdot 1$ & $3 \cdot 1+$ & $0 \cdot 8$ & - & - & - & - \\
\hline Alcoholic beverages & $2 \cdot 6$ & 0.5 & $1 \cdot 9+$ & $0 \cdot 3$ & $0 \cdot 8$ & 0.4 & $0 \cdot 4$ & $0 \cdot 1$ & - & - & - & - & $1 \cdot 8$ & $0 \cdot 3$ & $1 \cdot 3$ & $0 \cdot 3$ \\
\hline Mixtures & $1 \cdot 5 \mathrm{bt}$ & 0.2 & $0 \cdot 9+$ & $0 \cdot 1$ & $1 \cdot 6 t$ & $0 \cdot 3$ & $0 \cdot 6+$ & $0 \cdot 1$ & $4 \cdot 6+$ & $0 \cdot 8$ & $2 \cdot 7 \dagger$ & 0.5 & $1 \cdot 2 \dagger$ & $0 \cdot 2$ & $0 \cdot 6$ & $0 \cdot 1$ \\
\hline \multirow[t]{5}{*}{ Infant foods } & $0 \cdot 3$ & $0 \cdot 2$ & - & - & $0 \cdot 4$ & $0 \cdot 3$ & - & - & $0 \cdot 4$ & 0.3 & - & - & $0 \cdot 8$ & 0.5 & - & - \\
\hline & \multicolumn{16}{|c|}{ Coastal villages } \\
\hline & \multicolumn{4}{|c|}{ Energy } & & Prote & & & Vitam & $\mathrm{A} / \mathrm{prc}$ & o-vitamir & $n \mathrm{~A}$ & & $\mathrm{Fe}$ & & \\
\hline & Rainy ( $n$ & 221) & Dry $(n$ & 221) & Rainy ( $n$ & 221) & Dry $(n$ & 221) & Rainy ( & 221) & Dry $(n$ & 221) & Rainy $(r$ & 221) & Dry $(n$ & 221) \\
\hline & Mean & $\mathrm{SE}$ & Mean & SE & Mean & $\mathrm{SE}$ & Mean & SE & Mean & $\mathrm{SE}$ & Mean & SE & Mean & SE & Mean & $\mathrm{SE}$ \\
\hline Tubers/cereals/breads & $66 \cdot 2$ & 0.9 & $65 \cdot 3$ & 0.9 & $28 \cdot 7$ & $1 \cdot 0$ & $27 \cdot 1$ & 0.8 & $25 \cdot 8$ & $1 \cdot 5$ & $32 \cdot 8$ & $1 \cdot 7$ & $58 \cdot 1$ & $1 \cdot 2$ & $63 \cdot 1$ & $1 \cdot 3$ \\
\hline Meat/chicken/eggs & $2 \cdot 2$ & 0.2 & $1 \cdot 4$ & 0.2 & $7 \cdot 5 \S$ & $0 \cdot 8$ & $4 \cdot 3$ & 0.5 & $3 \cdot 8$ & 0.7 & $5 \cdot 2$ & $0 \cdot 7$ & $11 \cdot 4$ & $1 \cdot 1$ & $7 \cdot 9$ & $1 \cdot 0$ \\
\hline Fish/shellfish & $12 \cdot 9$ & 0.5 & $12 \cdot 2$ & 0.5 & $55 \cdot 8$ & $1 \cdot 4$ & $58 \cdot 1$ & $1 \cdot 2$ & $13 \cdot 1$ & $1 \cdot 3$ & $10 \cdot 6$ & $1 \cdot 0$ & $16 \cdot 6$ & $0 \cdot 8$ & $15 \cdot 6$ & $0 \cdot 7$ \\
\hline Vegetables & $4 \cdot 2$ & 0.3 & $3 \cdot 1$ & 0.2 & $1 \cdot 4$ & $0 \cdot 1$ & $2 \cdot 7$ & $0 \cdot 4$ & $45 \cdot 1$ & $2 \cdot 1$ & $31 \cdot 9$ & $1 \cdot 9$ & $5 \cdot 8$ & 0.4 & $3 \cdot 5$ & 0.3 \\
\hline Fruits & 0.6 & $0 \cdot 1$ & $0 \cdot 7$ & $0 \cdot 1$ & 0.2 & $0 \cdot 1$ & 0.3 & $0 \cdot 1$ & $0 \cdot 6$ & $0 \cdot 2$ & 1.9 & 0.4 & $0 \cdot 7$ & 0.2 & $0 \cdot 7$ & 0.2 \\
\hline Nuts/beans & $1 \cdot 0$ & 0.2 & 0.5 & $0 \cdot 1$ & $0 \cdot 6$ & $0 \cdot 1$ & $0 \cdot 2$ & $0 \cdot 1$ & $0 \cdot 2$ & $0 \cdot 1$ & $0 \cdot 2$ & $0 \cdot 1$ & $1 \cdot 1$ & $0 \cdot 2$ & $0 \cdot 3$ & $0 \cdot 1$ \\
\hline Milk/cheese & $1 \cdot 6$ & 0.6 & $1 \cdot 7$ & 0.6 & $1 \cdot 5$ & 0.5 & $1 \cdot 6$ & 0.6 & $1 \cdot 7$ & 0.5 & $2 \cdot 5$ & $0 \cdot 7$ & $0 \cdot 3$ & $0 \cdot 1$ & $0 \cdot 3$ & $0 \cdot 2$ \\
\hline Sugars/sweets & $2 \cdot 0$ & 0.2 & $3 \cdot 1$ & 0.3 & - & - & - & - & - & - & - & - & - & - & - & - \\
\hline Fats/oils & 0.5 & $0 \cdot 1$ & 0.5 & $0 \cdot 1$ & - & - & - & - & $0 \cdot 4$ & $0 \cdot 1$ & $0 \cdot 1$ & $0 \cdot 1$ & - & - & - & - \\
\hline Alcoholic beverages & $3 \cdot 5$ & 0.5 & $3 \cdot 5$ & 0.5 & $0 \cdot 4$ & $0 \cdot 1$ & $0 \cdot 7$ & $0 \cdot 1$ & - & - & - & - & $1 \cdot 6$ & 0.3 & $2 \cdot 4$ & 0.5 \\
\hline Mixtures & $4 \cdot 6$ & 0.3 & $6 \cdot 8$ & 0.3 & $3 \cdot 1$ & 0.4 & $3 \cdot 7$ & 0.4 & $8 \cdot 7$ & 0.9 & $13 \cdot 7$ & $1 \cdot 3$ & $2 \cdot 7$ & $0 \cdot 3$ & $3 \cdot 5$ & $0 \cdot 3$ \\
\hline Infant foods & $0 \cdot 4$ & $0 \cdot 3$ & 0.9 & $0 \cdot 4$ & $0 \cdot 6$ & $0 \cdot 4$ & $1 \cdot 2$ & 0.6 & $0 \cdot 6$ & $0 \cdot 4$ & 0.9 & 0.6 & $0 \cdot 8$ & $0 \cdot 6$ & $1 \cdot 6$ & $0 \cdot 8$ \\
\hline & & & & & & & & All vil & illages & & & & & & & \\
\hline & & Ener & & & & Prote & & & Vitan & $\mathrm{A} / \mathrm{prc}$ & o-vitamir & $n \mathrm{~A}$ & & $\mathrm{Fe}$ & & \\
\hline & Rainy ( $r$ & 477) & Dry $(n$ & 510) & Rainy ( $r$ & 477) & Dry $(n$ & 510) & Rainy ( & 477) & Dry $(n$ & 510) & Rainy ( & 477) & Dry $(n$ & 510) \\
\hline & Mean & SE & Mean & SE & Mean & SE & Mean & SE & Mean & SE & Mean & SE & Mean & SE & Mean & SE \\
\hline reals/breads & $65 \cdot 6 \S$ & 0.7 & $67 \cdot 2$ & $0 \cdot 7$ & $29 \cdot 5$ & $0 \cdot 7$ & $30 \cdot 0$ & 0.6 & $25 \cdot 5 \S$ & $1 \cdot 1$ & $29 \cdot 1$ & $1 \cdot 1$ & $52 \cdot 1 \S$ & $0 \cdot 8$ & $59 \cdot 7$ & 0.6 \\
\hline Meat/chicken/eggs & $4 \cdot 8$ & 0.3 & $4 \cdot 3$ & 0.3 & $22 \cdot 0$ & $1 \cdot 1$ & $19 \cdot 8$ & $1 \cdot 0$ & $2 \cdot 5^{\circ}$ & 0.4 & $3 \cdot 3$ & 0.4 & $16 \cdot 9^{\circ}$ & $0 \cdot 8$ & $16 \cdot 3$ & 0.8 \\
\hline Fish/shellfish & $7 \cdot 8$ & 0.3 & $7 \cdot 5$ & 0.3 & $35 \cdot 9$ & $1 \cdot 1$ & $39 \cdot 7$ & $1 \cdot 1$ & $7 \cdot 8$ & 0.7 & $5 \cdot 8$ & 0.5 & $10 \cdot 8$ & 0.5 & $10 \cdot 1$ & 0.4 \\
\hline Vegetables & $6 \cdot 7$ & 0.3 & $4 \cdot 3$ & $0 \cdot 2$ & $3 \cdot 0$ & $0 \cdot 2$ & $1 \cdot 7$ & 0.2 & $53 \cdot 3 \S$ & $1 \cdot 4$ & $45 \cdot 3$ & $1 \cdot 4$ & $8 \cdot 1 \S$ & 0.4 & $5 \cdot 8$ & $0 \cdot 2$ \\
\hline Fruits & $0 \cdot 9$ & $0 \cdot 1$ & $1 \cdot 6$ & $0 \cdot 1$ & $0 \cdot 7$ & $0 \cdot 1$ & $0 \cdot 9$ & $0 \cdot 1$ & $0 \cdot 7$ & $0 \cdot 1$ & $1 \cdot 5$ & $0 \cdot 2$ & $1 \cdot 7$ & $0 \cdot 2$ & $1 \cdot 8$ & $0 \cdot 1$ \\
\hline Nuts/beans & $2 \cdot 2$ & 0.2 & $1 \cdot 6$ & $0 \cdot 1$ & $3 \cdot 2$ & $0 \cdot 3$ & $1 \cdot 5$ & 0.2 & $0 \cdot 3$ & $0 \cdot 1$ & $1 \cdot 5$ & $0 \cdot 4$ & $4 \cdot 0$ & $0 \cdot 3$ & $2 \cdot 7$ & $0 \cdot 2$ \\
\hline Milk/cheese* & $2 \cdot 3$ & 0.6 & $3 \cdot 3$ & $0 \cdot 7$ & $2 \cdot 3$ & 0.6 & $3 \cdot 3$ & 0.7 & $2 \cdot 6$ & 0.6 & $3 \cdot 9$ & $0 \cdot 8$ & $1 \cdot 0$ & $0 \cdot 4$ & $1 \cdot 6$ & 0.4 \\
\hline Sugars/sweets & $2 \cdot 3$ & $0 \cdot 1$ & $2 \cdot 8$ & $0 \cdot 1$ & - & - & - & - & - & - & - & - & - & - & - & - \\
\hline Fats/oils & $0 \cdot 7$ & 0.2 & $0 \cdot 8$ & $0 \cdot 1$ & - & - & - & - & $0 \cdot 3$ & $0 \cdot 1$ & $1 \cdot 8$ & $0 \cdot 4$ & - & - & - & - \\
\hline Alcoholic beverages & $3 \cdot 0$ & 0.4 & $2 \cdot 6$ & 0.3 & $0 \cdot 6$ & 0.2 & 0.5 & $0 \cdot 1$ & - & - & - & - & $1 \cdot 8$ & 0.3 & $1 \cdot 7$ & 0.3 \\
\hline Mixtures & $2 \cdot 9$ & 0.2 & $3 \cdot 4$ & 0.2 & $2 \cdot 2$ & 0.2 & $2 \cdot 0$ & 0.2 & $6 \cdot 5$ & 0.6 & $7 \cdot 4$ & $0 \cdot 7$ & $2 \cdot 0$ & $0 \cdot 2$ & $1 \cdot 9$ & $0 \cdot 2$ \\
\hline Infant foods & 0.4 & 0.2 & $0 \cdot 4$ & 0.2 & 0.5 & 0.2 & 0.5 & 0.3 & 0.5 & 0.3 & $0 \cdot 4$ & $0 \cdot 4$ & $0 \cdot 8$ & 0.4 & $0 \cdot 7$ & 0.3 \\
\hline
\end{tabular}

*Includes breast milk.

tDifference between locations $(P<0 \cdot 01)$

‡Difference between locations $(P<0.05)$.

§Difference between seasons $(P<0 \cdot 01)$.

of 0.997 between the height of adults present in both seasons. Activity level could have been overestimated. More than $80 \%$ of adults were classified as active which includes a broad range of activities, many of which were probably not that vigorous. However, we did not have enough data for further verification. Energy requirements calculated from either actual or desirable weight were practically identical (results not shown). Therefore, the 
Table 6 Individual intakes of energy and nutrients by location and season: non-random sample from the Gamba Complex of Protected Areas, Gabon, 2000

\begin{tabular}{|c|c|c|c|c|c|c|c|c|c|c|c|c|}
\hline & \multicolumn{4}{|c|}{ Continental villages } & \multicolumn{4}{|c|}{ Coastal villages } & \multicolumn{4}{|c|}{ All villages } \\
\hline & \multicolumn{2}{|c|}{ Rainy (n 256) } & \multicolumn{2}{|c|}{ Dry (n 289) } & \multicolumn{2}{|c|}{ Rainy (n 221) } & \multicolumn{2}{|c|}{ Dry $(n$ 221) } & \multicolumn{2}{|c|}{ Rainy ( $n$ 477) } & \multicolumn{2}{|c|}{ Dry $(n 510)$} \\
\hline & Mean & SE & Mean & SE & Mean & SE & Mean & SE & Mean & SE & Mean & SE \\
\hline Energy (kJ) & $5825^{\star}$ & 102 & $5830^{*}$ & 91 & 6603 & 110 & 7548 & 110 & $6176+$ & 75 & 6623 & 71 \\
\hline Energy (kcal) & $1392 \cdot 1^{*}$ & $24 \cdot 4$ & $1393 \cdot 5^{\star}$ & $21 \cdot 8$ & $1578 \cdot 2$ & $26 \cdot 4$ & $1803 \cdot 9$ & $26 \cdot 4$ & $1476 \cdot 0+$ & $18 \cdot 0$ & $1583 \cdot 0$ & $17 \cdot 0$ \\
\hline Protein (g/4184 kJ) & $28 \cdot 7^{*}$ & $0 \cdot 2$ & $29 \cdot 0^{\star}$ & $0 \cdot 2$ & $35 \cdot 7$ & $0 \cdot 3$ & $35 \cdot 2$ & $0 \cdot 3$ & $31 \cdot 6$ & $0 \cdot 2$ & $31 \cdot 8$ & $0 \cdot 2$ \\
\hline Vitamin A/pro-vitamin A (RE/4184 kJ) & $514 \cdot 0^{*}$ & $11 \cdot 3$ & $348 \cdot 3^{*}$ & $7 \cdot 0$ & $272 \cdot 3$ & $6 \cdot 5$ & $204 \cdot 2$ & 4.9 & $384 \cdot 5+$ & $6 \cdot 2$ & $269 \cdot 7$ & $4 \cdot 1$ \\
\hline $\mathrm{Fe}(\mathrm{mg} / 4184 \mathrm{~kJ})$ & $6 \cdot 6^{*}$ & $0 \cdot 1$ & $6 \cdot 6^{*}$ & $0 \cdot 1$ & $5 \cdot 7$ & $0 \cdot 1$ & $5 \cdot 6$ & $0 \cdot 1$ & $6 \cdot 2$ & $0 \cdot 1$ & $6 \cdot 1$ & $0 \cdot 1$ \\
\hline
\end{tabular}

$\mathrm{RE}$, retinol equivalents.

${ }^{*}$ Difference between locations in each season $(P<0.01)$

tDifference between seasons $(P<0 \cdot 01)$.

Table 7 Degree of satisfaction (\%) of energy and nutrient requirements for each age group by location and season: non-random sample from the Gamba Complex of Protected Areas, Gabon, 2000

\begin{tabular}{|c|c|c|c|c|c|c|c|c|c|c|c|c|}
\hline \multirow[b]{3}{*}{ Age group } & \multicolumn{4}{|c|}{ Continental villages } & \multicolumn{4}{|c|}{ Coastal villages } & \multicolumn{4}{|c|}{ All villages } \\
\hline & \multicolumn{2}{|c|}{ Rainy } & \multicolumn{2}{|c|}{ Dry } & \multicolumn{2}{|c|}{ Rainy } & \multicolumn{2}{|c|}{ Dry } & \multicolumn{2}{|c|}{ Rainy } & \multicolumn{2}{|c|}{ Dry } \\
\hline & Mean & SE & Mean & SE & Mean & SE & Mean & SE & Mean & SE & Mean & SE \\
\hline 0-59 months* & $(n$ 34) & & $(n 48)$ & & $(n 31)$ & & $(n 36)$ & & $(n 65)$ & & $(n 84)$ & \\
\hline Energy & 91 & 3 & 89 & 3 & 84 & 3 & 107 & 3 & $88 \S$ & 2 & $97 \S$ & 2 \\
\hline Protein & 120 & 3 & 123 & 3 & 156 & 5 & 191 & 5 & $135 \S$ & 3 & $149 \S$ & 3 \\
\hline Vitamin A/pro-vitamin A & 110 & 5 & 102 & 4 & 56 & 3 & 77 & 4 & 80 & 2 & 89 & 3 \\
\hline $\mathrm{Fe}$ & 48 & 4 & 48 & 4 & 35 & 4 & 47 & 4 & $42 \S$ & 3 & $47 \S$ & 3 \\
\hline $5-9$ years & $(n 32)$ & & $(n 35)$ & & (n 32) & & $(n 33)$ & & $(n 64)$ & & $(n 68)$ & \\
\hline Energy & 68 & 3 & 71 & 3 & 82 & 3 & 97 & 3 & 74 & 2 & 82 & 2 \\
\hline Protein & 117 & 3 & 128 & 3 & 188 & 5 & 206 & 6 & 145 & 3 & 157 & 3 \\
\hline Vitamin A/pro-vitamin A & 121 & 6 & 84 & 4 & 57 & 3 & 71 & 4 & 85 & 3 & 76 & 3 \\
\hline $\mathrm{Fe}$ & 49 & 4 & 54 & 4 & 50 & 4 & 47 & 5 & 50 & 3 & 53 & 3 \\
\hline $10-19$ years & $(n$ 62) & & $(n 75)$ & & $(n 52)$ & & $(n 49)$ & & $(n 114)$ & & $(n$ 123) & \\
\hline Energy & 56 & 3 & 56 & 2 & 58 & 3 & 81 & 3 & 57 & 2 & 66 & 2 \\
\hline Protein & 92 & 2 & 93 & 2 & 128 & 3 & 159 & 4 & 107 & 2 & 117 & 2 \\
\hline Vitamin A/pro-vitamin A & 127 & 4 & 85 & 3 & 53 & 2 & 70 & 3 & 85 & 2 & 78 & 2 \\
\hline $\begin{array}{c}\mathrm{Fe} \\
20-59 \text { years }\end{array}$ & 50 & 3 & 53 & 3 & 43 & 3 & 54 & 4 & 46 & 2 & 54 & 2 \\
\hline 20-59 years & $(n 88)$ & & $(n 93)$ & & $(n 61)$ & & $(n 59)$ & & (n 149) & & $(n 151)$ & \\
\hline Energy & 65 & 2 & 66 & 2 & 69 & 3 & 80 & 2 & 67 & 2 & 72 & 1 \\
\hline Protein & 130 & 2 & 126 & 2 & 179 & 4 & 174 & 3 & 150 & 2 & 145 & 2 \\
\hline Vitamin A/pro-vitamin A & 144 & 4 & 90 & 3 & 61 & 2 & 60 & 2 & 97 & 2 & 76 & 2 \\
\hline $\begin{aligned} & \mathrm{Fe} \\
\geq & 60 \text { years }\end{aligned}$ & $\begin{array}{c}80 \\
(n 40)\end{array}$ & 3 & $\begin{array}{c}79 \\
(n 38)\end{array}$ & 3 & $\begin{array}{c}72 \\
(n 45)\end{array}$ & 4 & $\begin{array}{c}75 \\
(n 44)\end{array}$ & 4 & $\begin{array}{c}76 \\
(n 85)\end{array}$ & 2 & $\begin{array}{c}77 \\
(n 82)\end{array}$ & 3 \\
\hline Energy & 73 & 3 & 76 & 3 & 77 & 3 & 96 & 3 & 75 & 2 & 85 & 2 \\
\hline Protein & 120 & 3 & 131 & 3 & 158 & 4 & 194 & 5 & 136 & 2 & 155 & 3 \\
\hline Vitamin A/pro-vitamin A & 129 & 5 & 99 & 5 & 62 & 3 & 87 & 4 & 93 & 3 & 93 & 3 \\
\hline $\mathrm{Fe}$ & 98 & 5 & 96 & 6 & 77 & 6 & 98 & 6 & 88 & 4 & 97 & 4 \\
\hline All & $(n 256)$ & & (n 289) & & $(n 221)$ & & (n 221) & & $(n$ 477) & & $(n 510)$ & \\
\hline Energy & 71 & 1 & $72+$ & 1 & $74 \ddagger$ & 1 & 92 & 1 & 70 & 1 & 75 & 1 \\
\hline Protein & $120+$ & 2 & $122+$ & 1 & 167 & 2 & 189 & 2 & $132 \ddagger$ & 3 & 142 & 1 \\
\hline Vitamin A/pro-vitamin A & $119+$ & 2 & $86+$ & 2 & 55 & 2 & 67 & 2 & $97 \ddagger$ & 2 & 75 & 1 \\
\hline $\mathrm{Fe}$ & $65+$ & 4 & 67 & 2 & 56 & 2 & 66 & 2 & 56 & 3 & 59 & 1 \\
\hline
\end{tabular}

*The degree of satisfaction of Fe requirements was not assessed in children aged $<6$ months.

tDifference between locations $(P<0 \cdot 01)$.

fDifference between seasons $(P<0.01)$.

$\S$ Difference between age groups in each season $(P<0 \cdot 01)$.

discrepancy between nutritional status and the prevalence of inadequate energy intake in adults is probably due to our imprecise assessment of physical activity. Assuming the error is similar across the population, it is somewhat taken into account in the global score of nutrient adequacy; in addition, the latter also includes three other nutrients. The results are thus consistent with nutrient adequacy being a good predictor of nutritional status.

Among the elderly, we suspect that their diet improved because of the survey. Having people interested in their food could have led them to prepare more elaborate meals for increased attention. Contrary to younger adults, they were often living alone or as a couple and not as busy. 
(a)

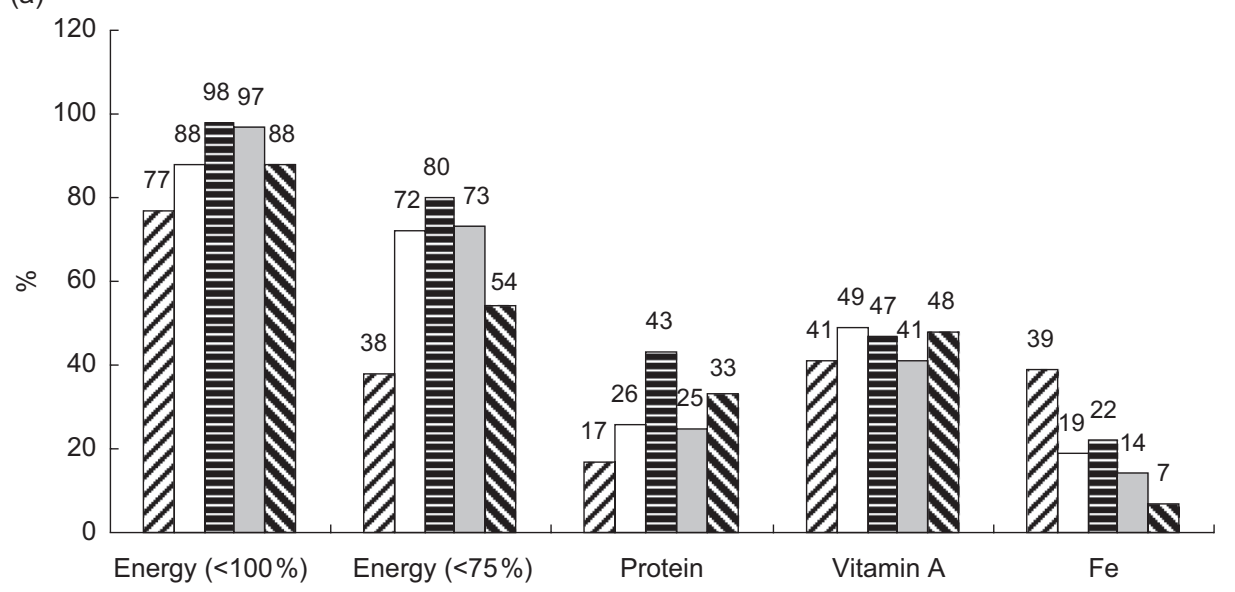

(b)

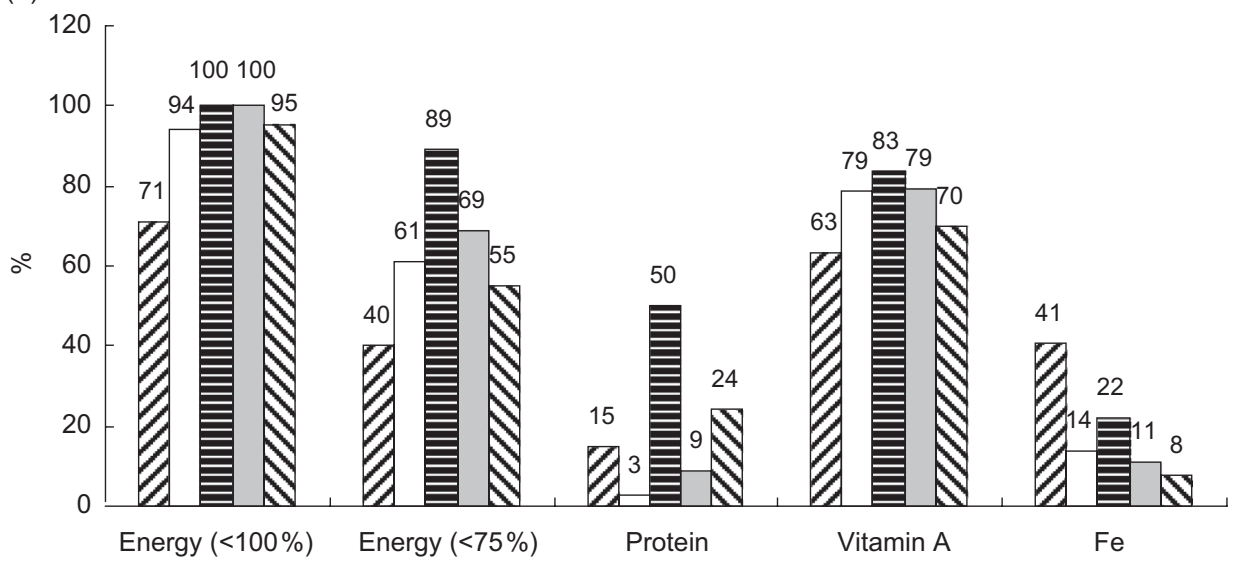

Fig. 2 Prevalence (\%) of inadequate nutrient intakes by age group ( $\geq, 0-59$ months; $\square, 5-9$ years; 三, 10-19 years; $\square$, 20-59 years; $\mathbb{N}, \geq 60$ years) in continental villages in the rainy season (a) and the dry season (b): non-random sample from the Gamba Complex of Protected Areas, Gabon, 2000

If they did modify their diet, their satisfaction of requirements would be even lower than what was observed. However, it is likely that their physical activity was also overestimated, thus further corroborating our results.

Although breast milk provided most of the energy for children aged $<6$ months, other sources, mainly puréed staples, likely displaced the more nutrient-dense breast milk. While breast milk still provided about 50\% of energy for children aged 6-11 months, staples were the main complementary foods. The low rate of exclusive breast-feeding before 6 months, the subsequent low frequency of nursing and the low nutrient density of complementary foods interfere with good nutrition. The intake of breast milk was estimated as precisely as possible; however, it should still be interpreted cautiously.

While requirements can be used to assess the apparent adequacy of an individual's dietary intake, the EAR is the relevant reference to assess the proportion of a population at risk of protein and vitamin A inadequacy. Overall, our results on the prevalence of inadequate intake of energy, protein, Fe and vitamin A followed a pattern similar to those on the satisfaction of requirements. However, the prevalence of inadequate intake of Fe was likely underestimated, since the reference data used to assess this risk were based on a diet with $18 \%$ of bioavailable $\mathrm{Fe}$ as no other data were available. It is likely that our population had a low risk of inadequate intake of protein. For vitamin A, those living in continental villages presented a moderate risk of inadequate intake during the rainy season.

Nevertheless, the prevalence of inadequate intakes for all nutrients examined is generally of concern. The deficit of energy is particularly striking. Many individuals of all ages, particularly adolescents, apparently do not eat enough. Although protein requirements were generally satisfied in all age groups, since energy requirements were largely unfulfilled, proteins were likely utilized to provide energy, probably creating a problem for children and adolescents. The very low intake of vitamin $\mathrm{A}$, the fact that most of its sources were of vegetable origin and its high prevalence of inadequacy in most age groups could favour the development of infections, especially 
(a)

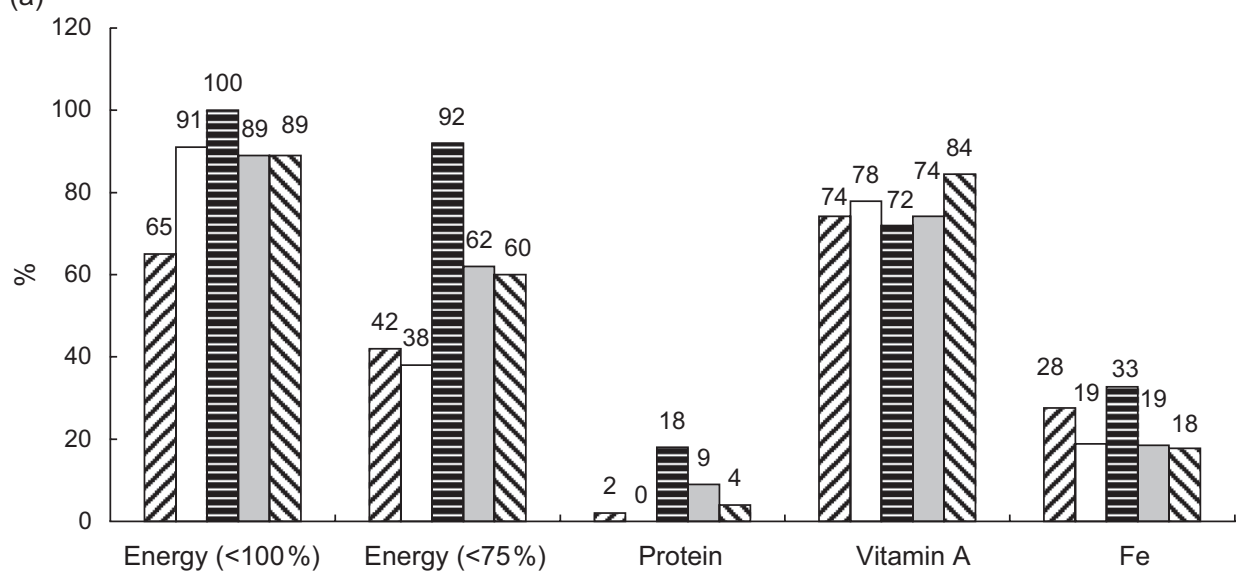

(b)

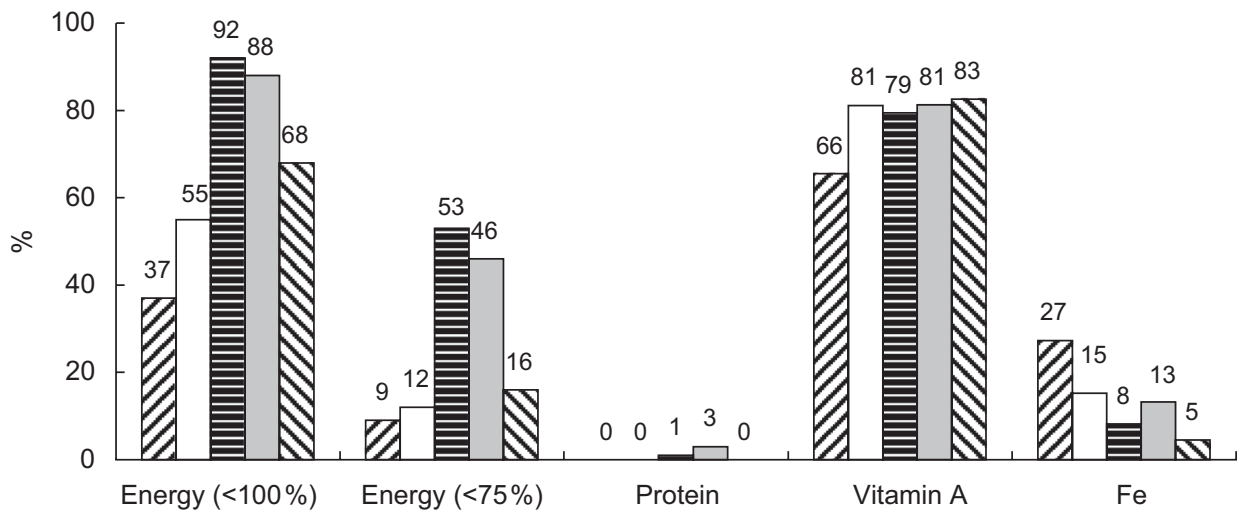

Fig. 3 Prevalence (\%) of inadequate nutrient intakes by age group ( $Z, 0-59$ months;,$- 5-9$ years; E, 10-19 years; $\square$, 20-59 years; $\mathbb{N}, \geq 60$ years) in coastal villages in the rainy season (a) and the dry season (b): non-random sample from the Gamba Complex of Protected Areas, Gabon, 2000

Table 8 Immediate determinants of nutritional status* in a non-random sample from the population of the Gamba Complex of Protected Areas, Gabon, 2000

\begin{tabular}{|c|c|c|c|c|}
\hline Model & Coefficient & $P$ value & OR ratio & $95 \% \mathrm{Cl}$ \\
\hline \multicolumn{5}{|l|}{ Model 1} \\
\hline Constant & -0.174 & $0 \cdot 746$ & 0.841 & \\
\hline Nutrient adequacy & $0 \cdot 364$ & 0.033 & $1 \cdot 439$ & $1 \cdot 030,2.009$ \\
\hline Health status (not sick) $\dagger$ & 0.549 & 0.009 & $1 \cdot 731$ & $1 \cdot 149,2 \cdot 609$ \\
\hline \multicolumn{5}{|l|}{ Model 2} \\
\hline Constant & 0.555 & $0 \cdot 320$ & $1 \cdot 741$ & \\
\hline Nutrient adequacy & 0.497 & 0.009 & $1 \cdot 644$ & $1 \cdot 131,2 \cdot 389$ \\
\hline Age group $(0-23$ months $) \ddagger$ & $-1 \cdot 477$ & 0.000 & $0 \cdot 228$ & $0.109,0.477$ \\
\hline Age group (24-59 months) & $-2 \cdot 408$ & 0.000 & 0.090 & $0.049,0.164$ \\
\hline Age group (5-9 years) $\ddagger$ & -0.681 & 0.033 & 0.506 & $0.271,0.946$ \\
\hline Age group $\geq 60$ years) $\ddagger$ & $-1 \cdot 105$ & 0.000 & 0.331 & $0.187,0.586$ \\
\hline
\end{tabular}

${ }^{*}$ Children aged $<5$ years with a length/height-for-age $Z$-score above -1 were considered well-nourished.

tReference category: sick.

†Reference category: adults (20-59 years).

among the most vulnerable ${ }^{(36)}$. The proportion of energy provided by fat could also have been a limiting factor for the absorption of pro-vitamin A. Among individuals who satisfied less than $75 \%$ of their vitamin A requirements, fat provided $19 \%$ of energy compared with $26 \%$ among those with a higher intake. Both are, however, well within the recommended range $(15-30 \%)^{(34)}$ and for example, green leaves, a source of pro-vitamin A, were always cooked with oil. While we were not able to estimate retinol activity equivalents, doing so would not likely improve the picture. Fe intakes were particularly deficient in groups whose requirements are especially high, also likely taking its toll on growth, development and work capacity ${ }^{(37)}$. Finally, it is possible that if each individual could eat enough of the 
same food to meet his/her energy requirements, their intake of vitamin $\mathrm{A}$ and $\mathrm{Fe}$ would be adequate.

Tubers, cereals and breads were major contributors to all nutrients. Meat/chicken/eggs in continental villages and fish/shellfish in coastal villages were important for protein and $\mathrm{Fe}$, while vegetables were important for vitamin A. Much fish/shellfish, meat/chicken/eggs and many vegetables are natural resources. Other foods such as tubers generally require deforestation for agricultural purposes. If legislation prohibiting the extraction of these resources were enforced, the nutritional situation could be much worse.

Since the study was not carried out in a randomly selected sample of villages, the results cannot necessarily be generalized to the whole rural population of the Complex. Nevertheless, the sample was intentionally selected to represent the population of continental and coastal locations (ethnic group) and access to market although neither proved to have a major influence on the parameters studied. The length of the study could have been increased and the results might have been more precise. However, the prevalence of inadequate intakes would likely still be important. Many safeguards were also used to improve the reliability of data throughout their collection and analysis, including close monitoring of surveyors, daily revisions of data and double coding of a random sample of $10 \%$ of data.

\section{Conclusion}

The present results provide an overview of the nutrition situation of the rural population living in the Complex. Inadequate intakes of nutrients are associated with undernutrition, particularly among children and the elderly. Among the former, improved breast-feeding practices would go a long way to improve nutritional status. In all groups, it appears that many individuals do not eat nearly enough food to satisfy even their energy requirements although much of their food does come from natural resources. This emphasizes the need to investigate this situation further to find ways to ensure that protection of natural resources will not be associated with harm to the well-being of local people.

The right to good nutrition has been recognized ${ }^{(38,39)}$. Undernutrition in all ages, but particularly in childhood, has severe and long-term consequences ${ }^{(40)}$. Undernutrition disempowers individuals by causing or aggravating illness. The potential intellectual and technical capacity of a population relies on enhanced nutrition. Conservation agencies cannot afford to create more protected areas without addressing the issue of the consequences for dwellers and neighbouring communities.

\section{Acknowledgements}

We are particularly grateful to the participants of the survey, to the nutrition survey team and to the Ministry of Water and Forests. The financial support of the MacArthur Foundation (grant no. 98-551194-GSS), the Dutch Directorate General for International Cooperation (DGIS) and the World Wide Fund for Nature (WWF) is acknowledged. We also thank the many persons who helped with this publication. The main author was employed by the WWF while planning and carrying out the survey although data analysis and interpretation were done subsequently and were entirely the responsibility of the authors. For the main author, this was part of the requirements for obtaining her $\mathrm{PhD}$ at Université Laval with the participation of her supervisors, the second and third authors. The last author contributed to the data collection and analysis of the socio-economic survey data which were used to define the population for this study. He also provided advice and logistical support during the data collection and analysis of the present study.

\section{References}

1. Pimentel D, McNair M, Buck L, Pimentel M \& Kamil J (1997) The value of forests to world food security. Hum Ecol 25, 91-120.

2. World Conservation Union/World Commission on Protected Areas (2000) Protected Areas - Benefits Beyond Boundaries. Gland, Switzerland: IUCN/WCPA.

3. Ministère de la Planification de l'Environnement et de l'Aménagement du Territoire (1993) Recensement général de la population et de l'habitat de 1993: résultats détaillés. Libreville, Gabon: MPEAT.

4. Ministère des Eaux et Forêts des Postes des Télécommunications et de l'Environnement (1996) Textes juridiques sur la protection des forêts, de l'environnement et de la faune au Gabon. Libreville, Gabon: Projet Forêts et Environnement/Ambassade du Canada.

5. United Nations Development Program (2005) Human Development Report 2005. New York: UNDP.

6. Direction Générale de la Statistique et des Études Économiques (DGSEE) \& ORC Macro (2001) Enquête démographique et de santé Gabon 2000. Libreville, Gabon/Calverton, MD: DGSEE/Fonds des Nations Unies pour la Population/ORC Macro.

7. Food and Agriculture Organization of the United Nations (2006) Gabon Food Balance Sheet. Rome: FAO.

8. Martorell R (1995) Promoting healthy growth: rationale and benefits. In Child Growth and Nutrition in Developing Countries: Priorities for Action, pp. 15-31 [P PinstrupAndersen, D Pelletier and H Alderman, editors]. Ithaca, NY: Cornell University Press.

9. UNICEF (1998) The State of the World's Children. New York: UNICEF.

10. Blaney S, Mbouity S, Moussounda Nzamba P, Nkombé J-M \& Thibault M (1998) Caractéristiques socio-économiques des populations du département de la Douigny et de Louango. Libreville, Gabon: WWF-Programme régional pour l'Afrique centrale.

11. Blaney S, Mbouity S, Nkombé J-M \& Thibault M (1997) Caractéristiques socio-économiques des populations des départements de Ndougou et de la Basse-Banio. Libreville, Gabon: WWF-Programme régional pour l'Afrique centrale.

12. Blaney S, Mboumba Mavoungou O, Mbouity S, Moussounda Nzamba P, Nkombé J-M \& Tondangoye J (1999) Caractéristiques socio-économiques des populations $d u$ département d'Étimboué. Libreville, Gabon: WWF-Programme régional pour l'Afrique centrale. 
13. Pekkarinen M (1970) Methodology in the collection of food consumption data. World Rev Nutr Diet 12, 145-171.

14. Thompson FE \& Byers $T$ (1994) Dietary assessment resource manual. J Nutr 124, 11 Suppl., 2245S-2317S.

15. World Health Organization (1995) Physical Status: The Use and Interpretation of Anthropometry. WHO Technical Report Series no. 854. Geneva: WHO.

16. Beaton GH (1994) Approaches to analysis of dietary data: relationship between planned analyses and choice of methodology. Am J Clin Nutr 59, 1 Suppl., 253S-261S.

17. Willett W (editor) (1998) Nature of variation in diet. In Nutritional Epidemiology, 2nd ed., pp. 33-49. New York: Oxford University Press.

18. Nyambose J, Koski KG \& Tucker KL (2002) High intra/ interindividual variance ratios for energy and nutrient intakes of pregnant women in rural Malawi show that many days are required to estimate usual intake. J Nutr 132, $1313-1318$.

19. Torres A, Willett W, Orav J, Chen L \& Huq E (1990) Variability of total energy and protein intake in rural Bangladesh: implications for epidemiological studies of diet in developing countries. Food Nutr Bull 12, 220-228.

20. Food and Agriculture Organization of the United Nations/ World Health Organization/United Nations University (2004) Human Energy Requirements. Report of Joint FAO/WHO/UNU Expert Consultation. Rome: FAO.

21. Multicentre Growth Reference Study Group (2006) WHO Child Growth Standards based on length/height, weight and age. Acta Paediatr Suppl 450, 76-85.

22. Pelletier D, Frongillo EJ \& Habicht J (1993) Epidemiologic evidence for a potentiating effect of malnutrition on child mortality. Am J Public Health 83, 1130-1133.

23. Pelletier D, Frongillo EA, Schroeder DG \& Habicht JP (1995) The effects of malnutrition on child mortality in developing countries. Bull World Health Organ 73, $443-448$.

24. Kuczmarski RJ, Ogden CL, Grummer-Strawn LM, Flegal KM, Guo SS, Wei R, Mei Z, Curtin LR, Roche AF \& Johnson CL (2000) CDC growth charts: United States. Adv Data 314 , $1-27$.

25. Brown K, Dewey KG \& Allen LH (1998) Complementary Feeding of Young Children in Developing Countries: A Review of Current Scientific Knowledge. WHO/NUT/98.1. Geneva: Program of Nutrition, Department of Family and Reproductive Health, WHO.

26. US Department of Agriculture (1999) Nutrient Database for Standard Reference, Release 13. Beltsville, MD: USDA, Agricultural Research Service, Nutrient Data Laboratory.

27. Heymans J-C (1982) Utilisation de la viande de chasse et élevage de certaines espèces animales au Zaïre et en RP Bénin. In Proceedings of the International Colloquium on
Tropical Animal Production for the Benefit of Man, Prince Leopold Institute of Tropical Medicine, Antwerp, 1982, pp. 267-279.

28. Ajayi S \& Tewe O (1983) A quantitative assessment of wildlife and their nutritive value as a source of food in Nigeria. In Nutrition and Food Policy in Nigeria, pp. 138-146 [L Atinmo and L Akinyele, editors]. Ibadan, Nigeria: National Institute for Policy and Strategic Studies, Ibadan University Press.

29. Miller J, Dip J \& Maggiore P (1993) Tables of Composition of Australian Aboriginal Foods. Canberra: Aboriginal Studies Press.

30. Food and Agriculture Organization of the United Nations/ World Health Organization/United Nations University (1986) Energy and Protein Requirements. WHO Technical Report Series no. 724. Geneva: WHO.

31. Food and Agriculture Organization of the United Nations/ World Health Organization (2001) Human Vitamin and Mineral Requirements. Report of a Joint FAO/WHO Expert Consultation. Rome: FAO.

32. Dewey K \& Brown K (2003) Update on technical issues concerning complementary feeding of young children in developing countries and implications for intervention programs. Food Nutr Bull 24, 5-28.

33. Institute of Medicine (2001) Dietary Reference Intakes: Applications in Dietary Assessment. Washington, DC: National Academy Press.

34. World Health Organization/Food and Agriculture Organization of the United Nations (2002) Diet, Nutrition and the Prevention of Chronic Diseases. Report of a Joint Expert Consultation. WHO Technical Report Series no. 916. Geneva: WHO.

35. Hosmer DW \& Lemeshow S (editors) (2000) Assessing the fit of the model. In Applied Logistic Regression, 2nd ed., pp. 159-167. New York: John Wiley and Sons, Inc.

36. Beaton GH, Martorell R, Kristan AA, Edmonston B, McCabe GA, Ross C \& Harvey B (1994) Vitamin A supplementation and child morbidity and mortality in developing countries. Food Nutr Bull 15, 282-289.

37. World Health Organization (2001) Functional consequences of iron deficiency. In Iron Deficiency AnaemiaAssessment, Prevention and Control: A Guide for Programme Managers, pp. 7-14. Geneva: WHO.

38. Assemblée Générale des Nations Unies (1989) Convention sur l'élimination de toutes les formes de discrimination à l'égard des femmes. New York: Nations Unies.

39. Assemblée Générale des Nations Unies (1989) Convention relative aux droits de l'enfant. New York: Nations Unies.

40. United Nations System Standing Committee on Nutrition (2004) The Fifth Report on the World Nutrition Situation. Geneva: SCN. 